\title{
GABAergic Network Activation of Glial Cells Underlies Hippocampal Heterosynaptic Depression
}

\author{
Alexandre Serrano, Nasser Haddjeri, Jean-Claude Lacaille, and Richard Robitaille \\ Centre de Recherche en Sciences Neurologiques et Département de Physiologie, Université de Montréal, Succursale Centre-Ville, Montréal, Québec, Canada \\ H3C $3 \mathrm{~J} 7$
}

Tetanus-induced heterosynaptic depression in the hippocampus is a key cellular mechanism in neural networks implicated in learning and memory. A growing body of evidence indicates that glial cells are important modulators of synaptic functions, but very little is known about their role in heterosynaptic plasticity. We examined the role of glial cells in heterosynaptic depression, knowing that tetanization and NMDA application caused depression of synaptic field responses (fEPSPs) and induced $\mathrm{Ca}^{2+}$ rise in glial cells. Here we report that chelating $\mathrm{Ca}^{2+}$ in a glial syncytium interfered with heterosynaptic depression and NMDA-induced fEPSP depression, suggesting that $\mathrm{Ca}^{2+}$ activation of glial cells is necessary for heterosynaptic depression. The NMDA-induced $\mathrm{Ca}^{2+}$ rise in glial cells was sensitive to tetrodotoxin and reduced by the $\mathrm{GABA}_{\mathrm{B}}$ antagonist CGP55845. Both heterosynaptic depression and simultaneous $\mathrm{Ca}^{2+}$ activation of glial cells were prevented by CGP55845, suggesting an involvement of the GABAergic network in glial activation and heterosynaptic depression. Also, the $\mathrm{GABA}_{\mathrm{B}}$ agonist baclofen caused both a $\mathrm{Ca}^{2+}$ rise in glial cells and fEPSP depression. Heterosynaptic depression, as well as NMDA- and baclofen-induced depression, were attenuated by an $\mathrm{A}_{1}$ antagonist, cyclopentyl-theophylline, whereas glial cell activation was not, indicating a role of adenosine downstream of glial activation. Finally, heterosynaptic depression requires ATP degradation because ectonucleotidase inhibitors reduced this plasticity. Our work indicates that $\mathrm{Ca}^{2+}$ activation of glial cells is necessary for heterosynaptic depression, which involves the sequential interaction of Schaffer collaterals, the GABAergic network, and glia. Thus, glial and neuronal networks are functionally associated during the genesis of heterosynaptic plasticity at mammalian central excitatory synapses.

Key words: neuron-glia interactions; heterosynaptic depression; GABA; GABA $\mathrm{B}$ receptors; NMDA; adenosine

\section{Introduction}

Multiple lines of evidence indicate that glial cells are active partners modulating neuronal activity (Auld and Robitaille, 2003a). In hippocampus, glial cells are known to sense synaptic activity at Schaffer collaterals (Dani et al., 1992; Pasti et al., 1997) and respond to such activity with rises in intracellular calcium levels (Porter and McCarthy, 1996; Carmignoto et al., 1998; Latour et al., 2001). After their $\mathrm{Ca}^{2+}$-mediated activation, hippocampal glial cells communicate with neurons to modulate both excitatory (Araque et al., 1998a,b, 2001; Pasti et al., 2001; Koizumi et al., 2003) and inhibitory synaptic transmission (Kang et al., 1998). Moreover, at the neuromuscular junction, activation of perisynaptic glial cells by synaptic activity is accompanied by feedback

\footnotetext{
Received June 30, 2005; revised April 10, 2006; accepted April 11, 2006.

This work was supported by a grant from the Natural Sciences and Engineering Research Council to R.R. and J.C.L. A.S. was supported by a fellowship from the Groupe de Recherche sur le Système Nerveux Central of the Fonds de la Recherche en Santé du Québec. N.H. was supported by a postdoctoral fellowship of the Canadian Institutes of Health Research (CIHR). J.-C.L. is the recipient of a Canada Research Chair in Cellular and Molecular Neurophysiology. R.R. is the recipient of a CIHR investigator award. We thank Carola Schipke for stimulating discussions and for comments on previous versions of this manuscript.

Correspondence should be addressed to Dr. Richard Robitaille, Département de Physiologie, Faculté de Médecine, Université de Montréal, C.P. 6128 Succursale Centre-ville, Montréal, Québec, Canada H3C 3J7. E-mail: richard.robitaille@umontreal.ca.

N. Haddjeri's present address: Laboratory of Neuropharmacology and Neurochemistry, Faculty of Pharmacy, University of Claude Bernard Lyon I, EA-512, 8 Avenue Rockefeller, 69373 Lyon Cedex 08, France.

D01:10.1523/JNEUROSC1.5255-05.2006

Copyright $\odot 2006$ Society for Neuroscience $\quad$ 0270-6474/06/265370-13\$15.00/0
}

modulation of synaptic efficacy and short-term plasticity (Robitaille, 1998; Auld and Robitaille, 2003a,b). Although a synapseglial-synapse regulatory loop has been identified in the periphery (Auld and Robitaille, 2003a), the involvement of glial cells in such a role at CNS synapses has only recently begun to be explored (Zhang et al., 2003; Pascual et al., 2005).

Interestingly, properties of glial cell activity and modulation are in register with the neuronal properties required to induce heterosynaptic plasticity in the CNS. For instance, frequencydependent synaptic transmission that activates glial cells is known to induce synaptic plasticity. In addition, the neurotransmitter and receptor systems that mediate synaptic plasticity are also implicated in the activation of glial cells (Haydon, 2001; Auld and Robitaille, 2003a). These characteristics are particularly striking when considering the production of hippocampal heterosynaptic depression. Heterosynaptic depression is a correlate of long-term potentiation (LTP) at Schaffer collateral synapses of the hippocampus (Lynch et al., 1977) and is believed to increase the contrast between potentiated and other nontetanized inputs on pyramidal neurons. Similar to LTP, heterosynaptic depression is dependent on NMDA receptor activation (Manzoni et al., 1994) in a frequency-dependent manner (Lynch et al., 1977). Additionally, heterosynaptic depression has been proposed to be mediated by local interneuron networks producing presynaptic inhibition of neurotransmitter release by adenosine (Manzoni et al., 1994). Interestingly, $\mathrm{Ca}^{2+}$-mediated activation of glial cells by 
hippocampal synaptic activity has been found to exhibit properties similar to those of heterosynaptic depression, such as dependence on NMDA receptor activation and stimulus frequency, and to involve adenosine release (Auld and Robitaille, 2003a). Finally, an elegant recent study has shown that integrity of the glial vesicular release machinery is necessary for complete induction of heterosynaptic depression (Pascual et al., 2005).

Hence, the present study was undertaken to determine the involvement of glial cells in heterosynaptic depression at Schaffer collateral synapses in hippocampal networks in situ. Our data show that glial cells in rat CA1 hippocampal slices are activated by $\mathrm{Ca}^{2+}$-mediated processes during heterosynaptic depression. Moreover, their activation involves local network interactions among afferent fibers, the GABAergic system, and glial cells and is necessary for heterosynaptic depression. These findings underscore a novel physiological interactive role for the GABAergic network and glial cells in synaptic plasticity at CNS synapses.

Parts of this paper have been published previously in abstract form (Serrano et al., 2003).

\section{Materials and Methods}

Hippocampal slices. Transverse hippocampal slices were obtained from young (14-21 d) male Sprague Dawley rats (Charles River, Montreal, Quebec, Canada) as described previously (Latour et al., 2001). Rats were anesthetized with halothane and decapitated with a guillotine. The brain was rapidly excised and placed in cold $\left(4-5^{\circ} \mathrm{C}\right)$, oxygenated $\left(95 \% \mathrm{O}_{2} / 5 \%\right.$ $\mathrm{CO}_{2}$ ) artificial CSF (ACSF) containing (in $\mathrm{mM}$ ): $124 \mathrm{NaCl}, 5 \mathrm{KCl}$ (except for baclofen experiments, in which $2 \mathrm{~mm} \mathrm{KCl}$ was used), $1.25 \mathrm{NaH}_{2} \mathrm{PO}_{4}$, $2 \mathrm{MgSO}_{4}, 2 \mathrm{CaCl}_{2}, 26 \mathrm{NaHCO}_{3}, 10$ glucose, and $50 \mu \mathrm{M}$ Trolox. A block of tissue containing the hippocampus was prepared, and transverse hippocampal slices ( $300 \mu \mathrm{m}$ thickness) were obtained in ACSF at $4^{\circ} \mathrm{C}$ with a Vibratome (Leica, Nussloch, Germany). Slices were transferred to a container filled with oxygenated ACSF at room temperature and allowed to recover for $1 \mathrm{~h}$.

Confocal microscopy and $\mathrm{Ca}^{2+}$ imaging. Cells were loaded with the fluorescent $\mathrm{Ca}^{2+}$ indicator fluo3-AM (Invitrogen, Eugene, OR), as described previously (Latour et al., 2001). Slices were incubated for $1 \mathrm{~h}$ at $37^{\circ} \mathrm{C}$ in oxygenated ACSF containing $30 \mu \mathrm{M}$ fluo3-AM, $0.5 \%$ dimethyl sulfoxide, and $0.02 \%$ pluronic acid (Invitrogen). After the incubation period, slices were returned to oxygenated ACSF at room temperature for $1 \mathrm{~h}$. Individual slices were then placed in a chamber mounted on the stage of an MRC-600 upright laser scanning confocal microscope (Bio-Rad, Hercules, CA) installed on an Olympus BH5 microscope (Tokyo, Japan) equipped with a $40 \times$ water-immersion objective $(0.75$ numerical aperture). The slice was submerged and perfused continuously with oxygenated ACSF $(2 \mathrm{ml} / \mathrm{min})$. Fluorescent glial cells were visually identified in stratum radiatum of the CA1 region, on the basis of their small soma diameter $(<10 \mu \mathrm{m})$ and their dispersed distribution [for detailed glial cell identification parameters, see below, Electrophysiology; also see Latour et al. (2001)]. The $488 \mathrm{~nm}$ excitation line of the laser was attenuated to $1 \%$ of maximum power, and emission was detected through a barrier filter with cutoff at $515 \mathrm{~nm}$. Similar ranges of gain (9-10) and black level (4.7-5.3) were used throughout the experiments to standardize $\mathrm{Ca}^{2+}$ responses. For $\mathrm{Ca}^{2+}$ imaging, time-lapse fluorescent images were collected every $2 \mathrm{~s}$ and recorded with MPL software (Bio-Rad). The images were further analyzed off-line with Image $(\mathrm{NIH})$ and Cfocal software (kindly provided by Dr. M. P. Charlton, University of Toronto, Toronto, Ontario, Canada). For each time-lapse image, the fluorescence intensity $(F)$ was averaged over the soma area. Before drug application, 100-300 control images were taken. Changes in fluorescence $(\Delta F)$ were measured as relative changes from baseline fluorescence and expressed as $\% \Delta F / F=$ $\left[\left(F_{\text {post }}-F_{\text {rest }}\right) / F_{\text {rest }}\right] \times 100$. For each $\mathrm{Ca}^{2+}$ response, the peak amplitude, the time-to-peak, the half-maximal recovery, and the area under the response, calculated with a trapezoidal rule-based algorithm (SigmaPlot, SPSS, Chicago, IL), were determined. $\mathrm{Ca}^{2+}$ responses were elicited by bath application ( $3 \mathrm{~min}$ ) of drugs or stimulation of the Schaffer collateral pathway (three trains at $100 \mathrm{~Hz}$ for $1 \mathrm{~s}$ at $30 \mathrm{~s}$ intervals). Cells in which the $\mathrm{Ca}^{2+}$ response did not recover to baseline were discarded from analysis.

The experimental procedure was as follows. Control $\mathrm{Ca}^{2+}$ responses and field EPSP (fEPSP) depression (see below, Electrophysiology) were recorded simultaneously from a slice and induced by bath application of drugs (NMDA and baclofen) or Schaffer collateral stimulation. Fifty minutes after the first agonist application or stimulation, $\mathrm{Ca}^{2+}$ responses and fEPSP recordings were again measured simultaneously in the same slice in the presence of blockers. The following blockers were applied to the whole slice via bath perfusion: D-2-amino-5-phosphonopentanoic acid (D-AP5; $50 \mu \mathrm{M})$, tetrodotoxin (TTX; $1 \mu \mathrm{M}),(R S)$ - $\alpha$-ethyl-4carboxyphenylglycine (E4CPG; $400 \mu \mathrm{M}), \quad(2 S)-3-[[(1 S)-1-(3,4-$ dichlorophenyl)ethyl]amino-2-hydroxypropyl] (phenylmethyl) phosphinic acid (CGP55845; $2 \mu \mathrm{M}$ ), 3-aminopropyl (diethoxymethyl) phosphinic acid (CGP35348; $500 \mu \mathrm{M}), \quad\left[\mathrm{S}-\left(R^{\star}, R^{\star}\right)\right]$-[3-[[1- $(3,4-$ dichlorophenyl) ethyl] amino]-2-hydroxypropyl] (cyclohexylmethyl) phosphinic acid (CGP54626; $0.1 \mu \mathrm{M})$, dipyridamole (DPM; $10 \mu \mathrm{M}$ ), 6- $N, N$-diethyl- $\{\beta\}$-dibromomethylene-D-adenosine-5' -triphosphate (ARL67156; $100 \mu \mathrm{M}$ ), and cyclopentyl-theophylline (CPT; $2 \mu \mathrm{M}$ ). $\mathrm{Ca}^{2+}$ responses were reproducible, and responses in control and in the presence of blockers were compared as paired experiments. The $\mathrm{Ca}^{2+}$ chelator 1,2-bis(2-aminophenoxy)ethane- $N, N, N^{\prime}, N^{\prime}$-tetra-acetic acid tetrapotassium salt (BAPTA) was dialyzed specifically in glial cells by using whole-cell recordings.

Electrophysiology. A micropipette filled with ACSF was positioned in stratum radiatum of the CA1 area to record fEPSPs, with an Axoclamp-2B amplifier (Molecular Devices, Union City, CA) in bridge mode. For tetanization-induced heterosynaptic depression, two ultrasmall concentric bipolar electrodes (Frederick Haer Co., Brunswick, ME) were placed in stratum radiatum for electrical stimulation of two independent Schaffer collateral pathways (test pathway: single pulse at 0.05 $\mathrm{Hz}, 100-900 \mu \mathrm{A}, 50-65 \mu$ s duration; tetanized pathway: three trains at $100 \mathrm{~Hz}$ for $1 \mathrm{~s}$ at $30 \mathrm{~s}$ intervals; same intensity as test pathway). For synaptic depression induced by NMDA $(25 \mu \mathrm{M})$ and baclofen $(20 \mu \mathrm{M})$, a single test pathway was used, and the agonist was bath applied for $3 \mathrm{~min}$. Electrophysiological signals were filtered at $1 \mathrm{kHz}$, digitized at $2 \mathrm{kHz}$ (TL-1; Molecular Devices), acquired, and analyzed on a PC with pClamp software.

For whole-cell recordings and BAPTA dialysis, pipettes were pulled from borosilicate glass (1 mm outer diameter; A-M Systems, Carlsborg, WA) and filled with the following (in $\mathrm{mm}$ ): $150 \mathrm{~K}$-methylsulfate, 1 $\mathrm{MgCl}_{2}, 8 \mathrm{NaCl}, 2$ ATP, 0.4 GTP, 10 HEPES, $0.15 \%$ biocytin, and 0.1 BAPTA (with $40 \mathrm{~mm}$ BAPTA, K-methylsulfate was omitted), titrated with $\mathrm{KOH}$ to $\mathrm{pH} 7.2-7.25$ and adjusted to $275-285$ mOsm (electrode resistance, 4-8 M $\Omega$ ). Whole-cell recordings were obtained from glial cells in stratum radiatum under visual guidance where fluorescent glial cells were previously identified with confocal microscopy. Whole-cell current-clamp recordings were made with an Axoclamp-2B amplifier (Molecular Devices) in bridge mode. The bridge balance was monitored regularly and adjusted with the bridge circuit.

Glial cells were identified based on the size $(<10 \mu \mathrm{m})$ and shape of the cells as observed under the fluorescent microscope, according to criteria in Latour et al. (2001). In addition, recorded cells showed no electrical excitability (no action potential produced) and had a low membrane potential (approximately $-80 \mathrm{mV}$ ) and a low membrane resistance $(<15$ $\mathrm{M} \Omega$ ). Most importantly, the recording of one glial cell usually resulted in the staining of a large number of glial cells by the biocytin included in the patch pipette. To our knowledge, only a certain category of astrocytes are electrically coupled to such an extent (Wallraff et al., 2004).

Histology. After whole-cell recordings, slices containing biocytin-filled cells were transferred to a freshly prepared solution of $4 \%$ paraformaldehyde in $0.1 \mathrm{~m}$ phosphate buffer and fixed for $4-12 \mathrm{~h}$ at $4^{\circ} \mathrm{C}$. Slices were washed and stored in $0.1 \mathrm{M}$ phosphate buffer and then embedded in agarose and resectioned at 50-80 $\mu \mathrm{m}$ thickness with a Vibratome. Sections were then processed with the Vectastain $\mathrm{ABC}$ kit (Vector Laboratories, Burlingame, CA), followed by nickel intensification as described previously (Woodhall et al., 1999). Sections were then mounted in D. P. X. medium (distyrene, plasticizer, and xylene mixture) and examined under a light microscope to count the number of labeled cells. 
Statistical analysis. Experiments were performed on the same slices in control and drug conditions. Thus, statistical significance of differences between groups was assessed with Student's paired $t$ test. The level of significance was set at $p<0.05$. SigmaStat statistical software (SPSS) was used for statistical analysis. All measures are expressed as mean \pm SEM.

\section{Results}

$\mathrm{Ca}^{2+}$-mediated activation of glial cells during heterosynaptic depression

We induced heterosynaptic depression in rat hippocampal slices by high-frequency stimulation of a subset of Schaffer collaterals (tetanized pathway: three trains at $100 \mathrm{~Hz}$ for $1 \mathrm{~s}$ at $30 \mathrm{~s}$ intervals) (Fig. $1 \mathrm{~A}$ ). Depression of synaptic transmission was measured in a different and independent set of Schaffer collateral-pyramidal cell synapses with field potential recordings (test pathway: single pulse stimulation at $0.05 \mathrm{~Hz}$ ) (Fig. 1A). High-frequency stimulation of the tetanized pathway induced a transient reduction of fEPSPs in the test pathway (Fig. $1 B, C$, top panels).

Heterosynaptic depression is known to be NMDA receptor dependent (Manzoni et al., 1994). In the presence of the NMDA receptor antagonist D-AP5 $(50 \mu \mathrm{M})$, two phases of fEPSP depression could be distinguished. A first short-lasting phase took place only seconds after tetanization and was independent of NMDA receptors (Fig. $1 B, E)$. A second slower phase lasting $>5$ min was significantly reduced by D-AP5 and was considered heterosynaptic depression (Fig. $1 B$, shaded area). For the group of slices tested, maximal heterosynaptic depression occurred at $2.2 \pm 0.1 \mathrm{~min}$ after the onset of high-frequency stimulation (Fig. 1C, top panel, D), and fEPSPs were depressed to $68.2 \pm 7.9 \%$ of baseline ( $n=5$ slices). In the presence of D-AP5, heterosynaptic depression was significantly reduced, and fEPSP amplitude remained at $87.9 \pm 8.1 \%$ of baseline $(n=5$ slices; Student's paired $t$ test; $p<0.05)$, reaching a peak at $1.6 \pm 0.5 \mathrm{~min}$ after tetanization.

A prerequisite for the involvement of glial cells in heterosynaptic depression is that they are activated by the stimulation protocol for heterosynaptic depression and this activation precedes the induction of the depression. We used simultaneous calcium imaging and fEPSP recordings to monitor variations of intracellular calcium levels $\left(\mathrm{Ca}^{2+}\right)$ in glial cells in close proximity $(\leq 100 \mu \mathrm{m})$ to the fEPSP recording electrode during heterosynaptic depression. The same stimulation protocol used to induce heterosynaptic depression also caused a $\mathrm{Ca}^{2+}$ elevation in glial cells (Fig.
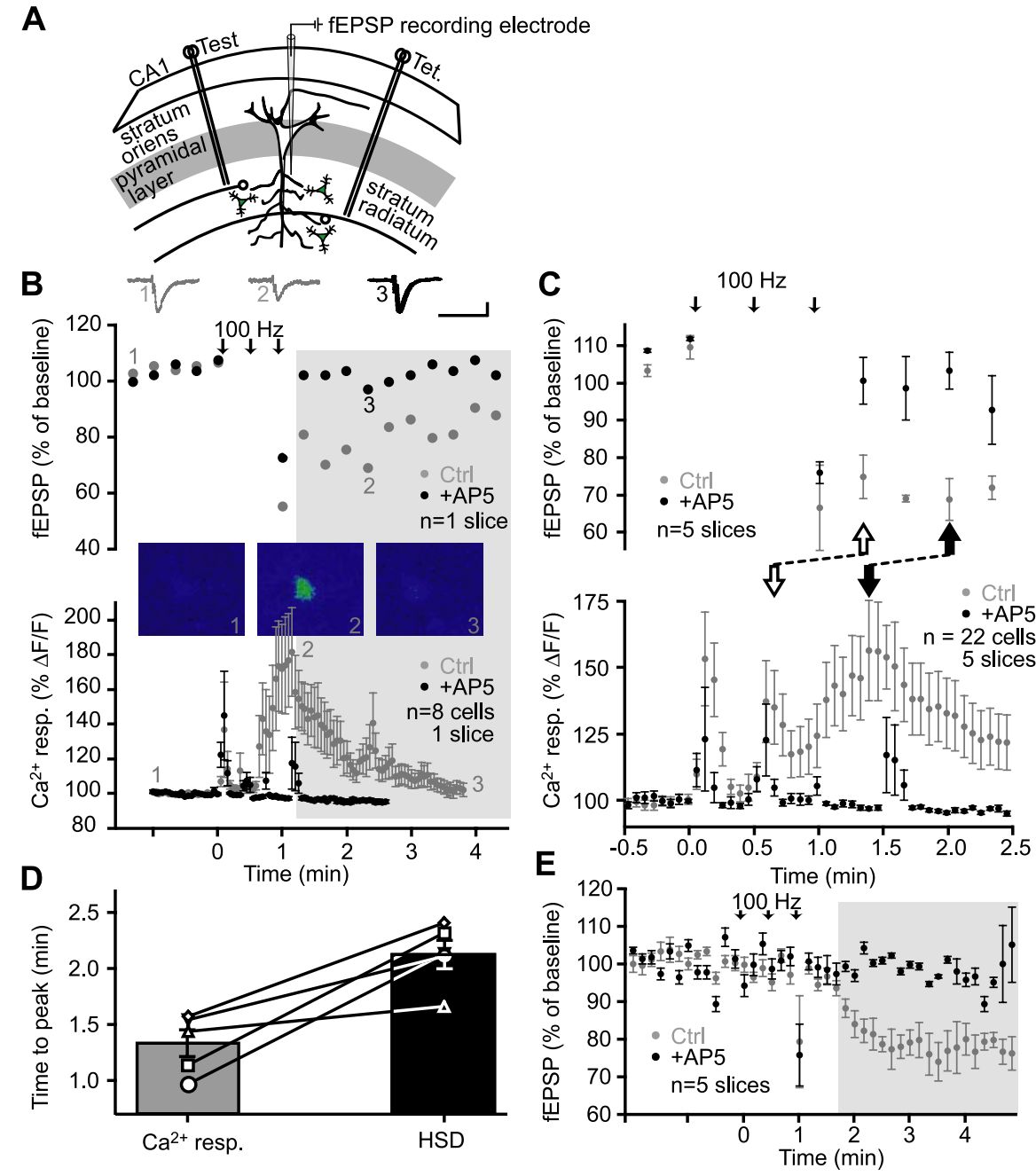

Figure 1. The $\mathrm{Ca}^{2+}$ rise in glial cells precedes heterosynaptic depression of fEPSPs. $A$, Schematic representation of area CA1 in a rat hippocampus slice, showing positions of two stimulating electrodes [Test; Tet. (tetanus)] and a single fEPSP recording electrode placed in the stratum radiatum. $\boldsymbol{B}$, Top panel, Representative example of changes in fEPSP amplitude in the test pathway of a single slice experiment, expressed as percentage of baseline, before and after tetanic stimulation of a separate pathway (arrows) (3 trains at $100 \mathrm{~Hz}$ for $1 \mathrm{~s} ; 30$ s intervals), showing heterosynaptic depression in control (gray) and its block by the NMDA receptor antagonist D-AP5 (50 $\mu \mathrm{m}$; black). In these and the following experiments, control and antagonist applications were paired, and effects were measured in the same slices. The shaded area represents the period during which NMDA receptordependent heterosynaptic depression occurs. Insets show examples of fEPSPs before (1) and during (2) heterosynaptic depression in control, and in D-AP5 (3). Bottom panel, Relative increase in fluorescence for glial cells from the same slice as in the top panel before, during, and after tetanic stimulation (as indicated in the top panel) in control (gray) and in the presence of D-AP5 (black). Stimulation elicited glial $\mathrm{Ca}^{2+}$ responses that were blocked by $50 \mu \mathrm{m} \mathrm{D}-\mathrm{AP} 5$ ( $n=8 \mathrm{glial}$ cells). Insets show pseudocolor (blue $=$ low level of $\mathrm{Ca}^{2+}$; red = high level) confocal images of a fluo-3-loaded glial cell before (1), during (2), and after (3) tetanusinduced elevation of $\mathrm{Ca}^{2+}$. C, Top panel, changes in average fEPSP amplitude ( $n=5$ slices) in the test pathway expressed as percentage of baseline, before and after tetanic stimulation of a separate pathway (arrows) (3 trains at $100 \mathrm{~Hz}$ for $1 \mathrm{~s} ; 30 \mathrm{~s}$ intervals), showing heterosynaptic depression in control (gray) and its block by the NMDA receptor antagonist D-AP5 (50 $\mu$ m; black). Bottom panel, Average relative increase in fluorescence ( $n=5$ slices, 22 glial cells) for glial cells from the same experiments as in the top panel before, during, and after tetanic stimulation (as indicated in the top panel) in control (gray) and in the presence of D-AP5 (black). Stimulation elicited glial $\mathrm{Ca}^{2+}$ responses that were blocked by $50 \mu \mathrm{M} \mathrm{D}-\mathrm{AP} 5$. Note that only a period of $3 \mathrm{~min}$ ( 30 s before induction and $2.5 \mathrm{~min}$ after) is shown to illustrate the timing of the induction of the glial $\mathrm{Ca}^{2+}$ response and of NMDA-dependent heterosynaptic depression. The onset (open arrows) of the sustained glial $\mathrm{Ca}^{2+}$ response precedes the onset of NMDA-dependent heterosynaptic depression. Likewise, the peak of the $\mathrm{Ca}^{2+}$ response (filled arrow) also precedes the peak of the NMDA-dependent heterosynaptic depression. D, Time-to-peak of the $\mathrm{Ca}^{2+}$ rises in glial cells simultaneously recorded with heterosynaptic depression of fEPSPs for each individual slice (open symbols, full lines). The bar graph represents the mean time-to-peak of $\mathrm{Ca}^{2+}$ responses and depression of fEPSPs for all slices. The mean timeto-peak of $\mathrm{Ca}^{2+}$ rises in glial cells is significantly shorter than the mean time-to-peak of heterosynaptic depression $(n=$ 5 slices; Student's paired $t$ test; $p<0.01$ ). $\boldsymbol{E}$, Average changes in fEPSP amplitude expressed as percentage of baseline for five experiments before, during, and after tetanic stimulation of Schaffer collaterals (arrows) ( 3 trains at $100 \mathrm{~Hz}$ for $1 \mathrm{~s} ; 30 \mathrm{~s}$ intervals). Heterosynaptic depression (control; gray) was blocked by the NMDA receptor antagonist D-AP5 (50 $\mu \mathrm{m}$; black). Note that NMDA-dependent heterosynaptic depression (shaded area) is induced after the third train of stimulation at 100 Hz. Ctrl, Control; HSD, heterosynaptic depression; resp., response. 

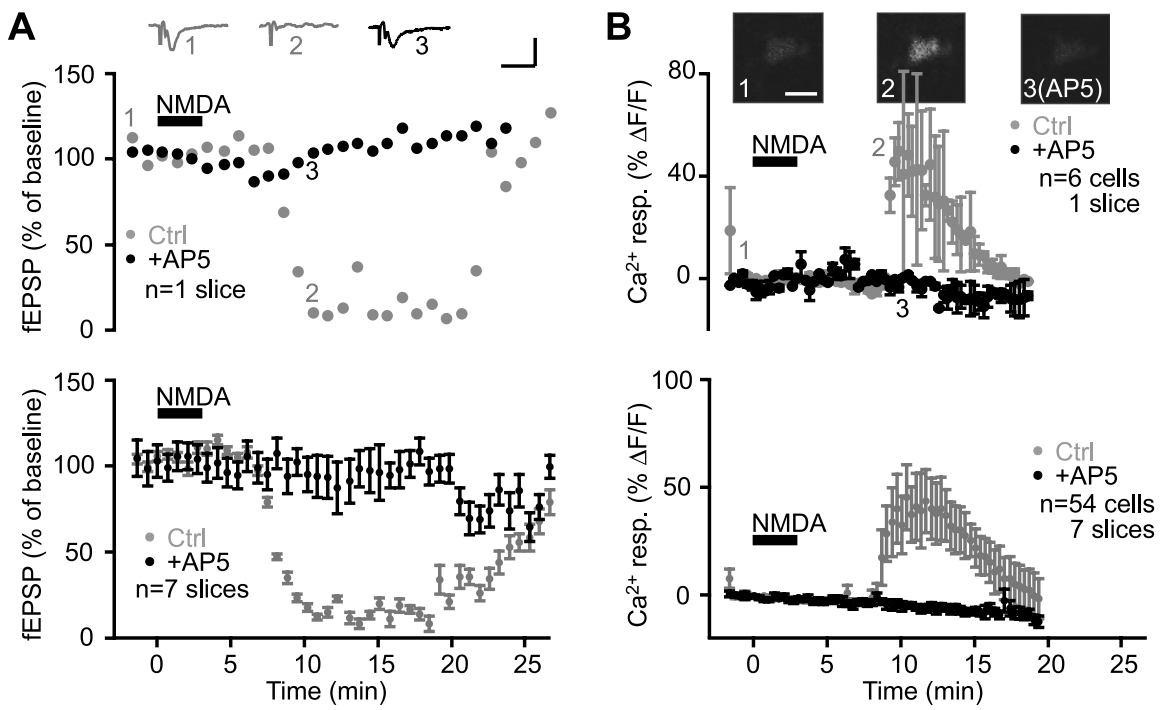

Figure 2. Intracellular $\mathrm{Ca}^{2+}$ rise in glial cells and fEPSP depression induced by NMDA application. $\boldsymbol{A}$, Representative single experiment (top panel; $n=1$ slice) and group data (bottom panel; $n=7$ slices) showing changes in fEPSP amplitude expressed as percentage of baseline before, during, and after NMDA bath application ( $25 \mu \mathrm{m} ; 3 \mathrm{~min}$ ) (bar) in paired control experiments and in the presence of D-AP5 $(50 \mu \mathrm{M})$. Bath application of NMDA induced a reduction of fEPSP that was prevented by $50 \mu \mathrm{M} \mathrm{D}-\mathrm{AP} 5(n=$ 7 slices; Student's paired $t$ test; $p<0.001$ ). Top insets show examples of fEPSPs before (1) and during (2) synaptic depression in control and in the presence of D-AP5 (3) (calibration: $0.5 \mathrm{mV}, 40 \mathrm{~ms}$ ). $\boldsymbol{B}$, Relative increase (mean $\pm \mathrm{SEM}$ ) in fluorescence for glial cells in the individual slice shown in $\boldsymbol{A}$ (top panel; $n=6$ cells) and for all slices (bottom panel; $n=54$ cells, 7 slices) before, during, and after NMDA bath application in control (gray) and in the presence of D-AP5 (black). NMDA elicited glial Ca ${ }^{2+}$ responses that were prevented by $50 \mu \mathrm{m}$ D-AP5 (Student's paired $t$ test; $p<0.001$ ). Responses obtained in control and in the presence of $\mathrm{D}-A P 5$ were obtained from the same slices as in $\boldsymbol{A}$. Top insets show pseudocolor (blue-red scale) confocal images of a glial cell loaded with fluo3-AM before (1) and during (2) NMDA-induced elevation of $\mathrm{Ca}^{2+}$ in control, and in the presence of D-AP5 (3). Scale bar, 10 $\mu \mathrm{m}$. Ctrl, Control; resp., response.

$1 B$, bottom panel; mean response from eight glial cells in the single field recording experiment is shown in the top panel). Stimulation-induced $\mathrm{Ca}^{2+}$ elevations in glial cells were also blocked by the NMDA receptor antagonist D-AP5 (Fig. $1 B, C$, bottom panel). Importantly, in every slice examined in control conditions, $\mathrm{Ca}^{2+}$ responses were elicited in glial cells during the three trains of stimuli, as well as after the trains, and these glial $\mathrm{Ca}^{2+}$ responses preceded the occurrence of heterosynaptic depression (Fig. $1 C, D$ ). For the five slices examined, the mean timeto-peak of $\mathrm{Ca}^{2+}$ responses of all glial cells in a given slice (1.34 \pm $0.12 \mathrm{~min}$ ) was significantly less than the mean time-to-peak of fEPSP heterosynaptic depression $(2.14 \pm 0.13 \mathrm{~min}$; Student's paired $t$ test; $p<0.01$ ) (Fig. $1 C, D$ ). These results indicate that the peak latency of $\mathrm{Ca}^{2+}$ rises in glial cells evoked by Schaffer collateral stimulation preceded that of heterosynaptic depression. Hence, the requirement that activation of glial cells takes place before the occurrence of the synaptic depression is fulfilled.

We recorded fEPSPs in the test pathway between tetani to test whether the EPSP amplitude was depressed during the stimulation period. In these slices, fEPSP amplitude between trains of stimulation was not significantly different from baseline amplitude ( $n=5$ slices; Student's paired $t$ test; $p>0.7$ ) (Fig. $1 E$ ). These observations suggest that heterosynaptic depression develops after the third train of stimulation and, hence, that glial cells are activated before the development of tetanus-induced heterosynaptic depression. Because others, in contrast, have reported heterosynaptic depression after a single train of stimulation (Pascual et al., 2005, Manzoni et al., 1994), the variability in the induction of heterosynaptic depression indicates that it is important to examine the temporal relationship between glial $\mathrm{Ca}^{2+}$ responses and depression of synaptic responses in the same experiments, as was done in the present study.

\section{Can heterosynaptic depression be mimicked pharmacologically?}

Given the role of NMDA receptors in tetanus-induced heterosynaptic depression and $\mathrm{Ca}^{2+}$ activation of glial cells, we examined the effects of NMDA on fEPSPs and glial cell $\mathrm{Ca}^{2+}$ levels. Bath application of NMDA $(25 \mu \mathrm{M})$ depressed fEPSPs to $4.2 \pm 5.1 \%$ of baseline with a maximal reduction occurring at $16.8 \pm 1.4 \mathrm{~min}$ after the onset of drug application (Fig. 2A). NMDA-induced depression was prevented by the NMDA receptor antagonist D-AP5 (50 $\mu \mathrm{M}$; Student's paired $t$ test; $p<$ 0.001 ) (Fig. 2A). Interestingly, the same NMDA application also caused a transient elevation of $\mathrm{Ca}^{2+}$ in glial cells (Fig. $2 \mathrm{~B}$ ). The relative increase of $\mathrm{Ca}^{2+}$ in glial cells reached a peak of $64.4 \pm 4.3 \% \Delta F / F$, with a latency of $11.5 \pm 0.5 \mathrm{~min}$ after the onset of NMDA application, and recovered to halfmaximal effect at $14.4 \pm 0.8 \mathrm{~min}$ after the onset of drug application. The slow kinetics of the $\mathrm{Ca}^{2+}$ responses may be the result of the bath application of the agonist (see also Porter and McCarthy, 1995; Kang et al., 1998). The NMDA-induced rise of $\mathrm{Ca}^{2+}$ in glial cells was blocked by the NMDA receptor antagonist D-AP5 (50 $\mu \mathrm{M} ; n=54$ cells from seven slices; Student's paired $t$ test; $p<$ 0.001 ) (Fig. $2 B$ ). Hence, the depression induced by NMDA application and tetanus stimulation are NMDA dependent, suggesting that NMDA application can be used as a pharmacological tool to study the mechanisms of heterosynaptic depression.

\section{Is $\mathrm{Ca}^{2+}$-mediated activation of glial cells necessary for heterosynaptic depression?}

To test whether $\mathrm{Ca}^{2+}$-mediated glial cell activation was necessary for the induction of heterosynaptic depression, we blocked glial $\mathrm{Ca}^{2+}$ responses by intracellular dialysis of the $\mathrm{Ca}^{2+}$ chelator BAPTA in glial cells with whole-cell recordings. BAPTA was dialyzed during recordings from a single glial cell via a patch pipette that also contained biocytin to visualize a syncytium of glial cells that was labeled after NMDA application $(\sim 20-200$ biocytinlabeled glial cells covering an area $\sim 300 \mu \mathrm{m}$ in diameter) (Fig. $3 A$ ) (see also Latour et al., 2001). Intracellular labeling with Oregon-green BAPTA, a $\mathrm{Ca}^{2+}$ indicator of the BAPTA family (with a higher molecular weight than BAPTA alone), revealed a similar spread into the glial syncytium after NMDA application, thus indicating that dialyzed BAPTA had spread into the syncytium (Fig. 3B, green cells). Identification of glial cells was confirmed by electrophysiological criteria (low resting membrane potential and absence of action potential); they were clearly different from interneurons in the same layer (Fig. $3 B$, red).

We next tested the effect of dialyzed BAPTA on NMDAinduced $\mathrm{Ca}^{2+}$ responses. In control conditions, with a low concentration of BAPTA $(0.1 \mathrm{~mm})$ dialyzed into glial cells, the NMDA-induced $\mathrm{Ca}^{2+}$ rise was reduced to $60.7 \pm 4.6 \%$ of control (Student's paired $t$ test; $p<0.02$ ) (Fig. $3 D$ ) because of the normal 

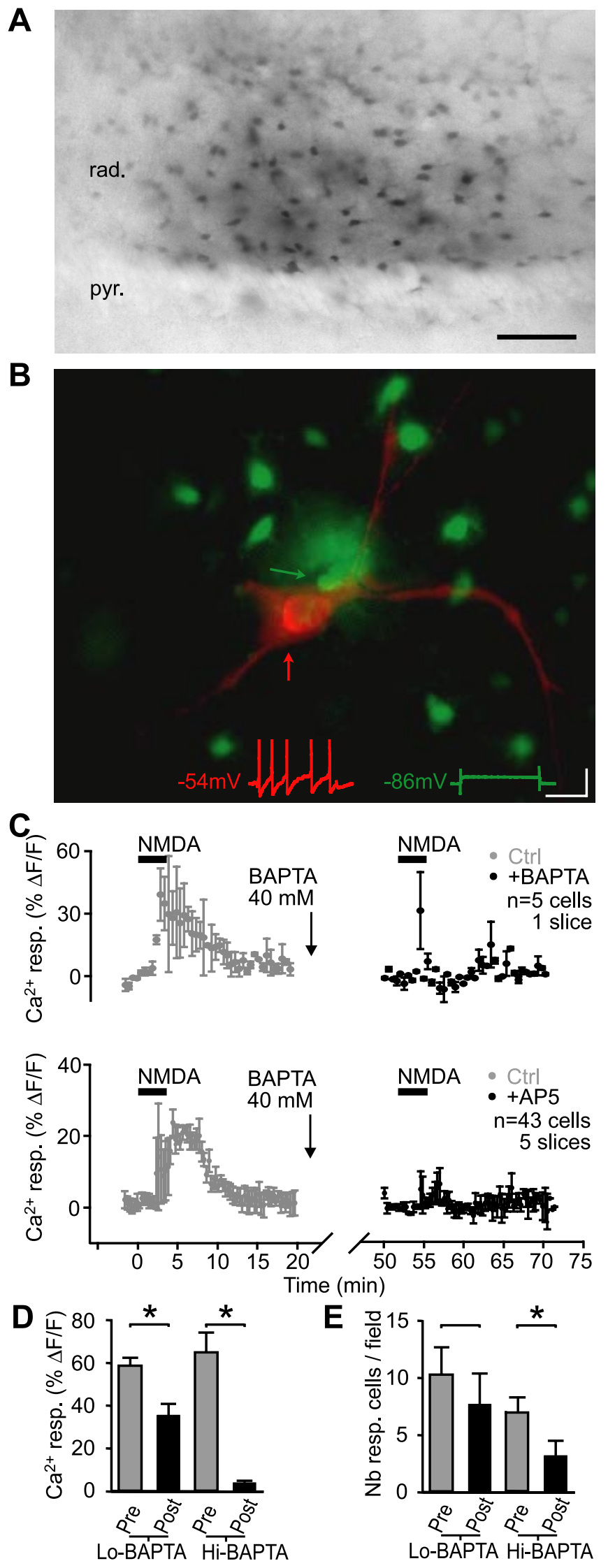

Figure 3. Dialysis of BAPTA in glial cells blocked the $\mathrm{Ca}^{2+}$ rise induced by NMDA. $A$, Syncytium of glial cells in CA1 stratum radiatum labeled with biocytin after whole-cell recording of a single glial cell with a patch pipette containing BAPTA ( $40 \mathrm{~mm}$ ) after NMDA application. Scale bar, $50 \mu \mathrm{m}$. B, Syncytium of glial cells (green) in CA1 stratum radiatum labeled with Oregon- rundown of fluorescence (see also Latour et al., 2001) (see Fig. $5 A$ ); however, after a high concentration of BAPTA (40 mM) was dialyzed in glial cells, the NMDA-induced rise of $\mathrm{Ca}^{2+}$ after BAPTA was significantly reduced to $6.3 \pm 5.1 \%$ of control $(n=$ 43 cells in five slices; Student's paired $t$ test; $p<0.01$ ) (Fig. $3 C, D$ ). Hence, dialysis of a high concentration of BAPTA caused a $93.7 \%$ reduction of an NMDA-induced rise of $\mathrm{Ca}^{2+}$ in glial cells that was significantly larger than the $39.3 \%$ reduction caused in control with a low concentration of BAPTA (Student's $t$ test; $p=$ 0.01 ). Additionally, in control conditions, dialysis of a low concentration of BAPTA $(0.1 \mathrm{~mm})$ did not reduce significantly the number of responsive glial cells $(74.8 \pm 23.3 \%$ of control; Student's paired $t$ test; $p>0.2$ ) (Fig. $3 E$ ). Conversely, the number of responsive glial cells after the dialysis of a high concentration of BAPTA (40 mM) was significantly reduced to $45.7 \pm 18.6 \%$ of control (Student's paired $t$ test; $p=0.01$ ) (Fig. $3 E$ ). Importantly, the basic properties of glial cells were not affected during these experiments. Indeed, in $40 \mathrm{~mm}$ BAPTA, membrane potential $\left(E_{\mathrm{M}}=\right.$ approximately $\left.-80 \mathrm{mV}\right)$ and membrane resistance $\left(R_{\mathrm{M}}=\sim 15 \mathrm{M} \Omega\right)$ were similar to control values. Moreover, in another series of experiments, the depolarization of glial cells induced by NMDA was unaffected by $40 \mathrm{~mm}$ BAPTA (A. Serrano, R. Robitaille, and J.-C. Lacaille, unpublished observations). Hence, glial cells appeared intact and functional. As a whole, these results indicate that the dialysis of $40 \mathrm{~mm}$ BAPTA via wholecell recordings impaired $\mathrm{Ca}^{2+}$ activation induced by NMDA in a significant number of glial cells.

We next evaluated the effect of preventing $\mathrm{Ca}^{2+}$-mediated activation of glial cells on heterosynaptic depression (Fig. $4 A$ ). In control conditions, with a low concentration of BAPTA $(0.1$ $\mathrm{mM}$ ), there was no significant change in heterosynaptic depression in the same slices before and after BAPTA dialysis in glial cells ( $n=7$ slices) (Fig. $4 B$ ). The peak of the initial phase, the time-to-peak, and the amplitude of the sustained phase measured 5 min after induction of heterosynaptic depression were unchanged (Student's paired $t$ test; $p>0.3$ ). In contrast, in separate experiments with $40 \mathrm{~mm}$ BAPTA dialyzed in glial cells, heterosynaptic depression was significantly reduced and recovered faster (Fig. 4C,D). In these experiments, before BAPTA dialysis, tetanization depressed fEPSP amplitude to $13.2 \pm 4.6 \%$ of baseline at the peak of the initial phase and to $53.3 \pm 5.2 \%$ of baseline during the sustained phase ( 5 min after tetanization), with half-maximal recovery occurring at $3.5 \pm 1.2 \mathrm{~min}$ after tetanization. After 40 mM BAPTA dialysis in glial cells, the NMDA-independent initial

$\leftarrow$

green BAPTA after whole-cell recording from a single glial cell (green arrow) after NMDA application. An adjacent interneuron (red) was subsequently recorded in whole-cell mode with Alexa594 in the patch pipette solution (red arrow). Insets show current-clamp recordings from the glial cell (green trace) and the interneuron (red trace) in response to the same depolarizing current step. Calibration: $200 \mathrm{~ms}, 20 \mathrm{mV}$. C, Relative increase (mean \pm SEM) in fluorescence for glial cells in a single slice (top panel; $n=5$ cells) and for all slices (bottom panel; $n=43$ cells, 5 slices) before, during, and after NMDA bath application (bars) in control ( $t=0-20 \mathrm{~min}$; gray) and after intracellular dialysis of $40 \mathrm{~mm}$ BAPTA into glial cells ( $t=50-70 \mathrm{~min}$; black; paired experiments). BAPTA was dialyzed during whole-cell patch recording from a single glial cell for the period indicated by the break in the time axis. This period was necessary to allow BAPTA diffusion in the glial syncytium. After BAPTA dialysis ( $t=50-70 \mathrm{~min}$ ), the glial $\mathrm{Ca}^{2+}$ rise induced by NMDA was significantly reduced (Student's paired $t$ test; $p<0.01$ ). D, Bar graphs showing the amplitude of NMDA-induced glial $\mathrm{Ca}^{2+}$ responses in control (pre-BAPTA dialysis in glial cells; shown as Pre in gray) and after BAPTA dialysis in glial cells (with either $0.1 \mathrm{~mm} \mathrm{BAPTA}$ (Lo-BAPTA) or 40 mm BAPTA (Hi-BAPTA) in pipette; shown as Post in black). $\boldsymbol{E}$, Bar graphs showing the number of glial cells responding (Nb resp. cells/field) to NMDA in control (Pre) and after dialysis of $0.1 \mathrm{~mm}$ BAPTA (Lo-BAPTA) or $40 \mathrm{~mm}$ BAPTA (Hi-BAPTA). Error bars indicate SEM. pyr., Pyramidal; rad., stratum radiatum; resp., response. ${ }^{*} p<0.05$. 

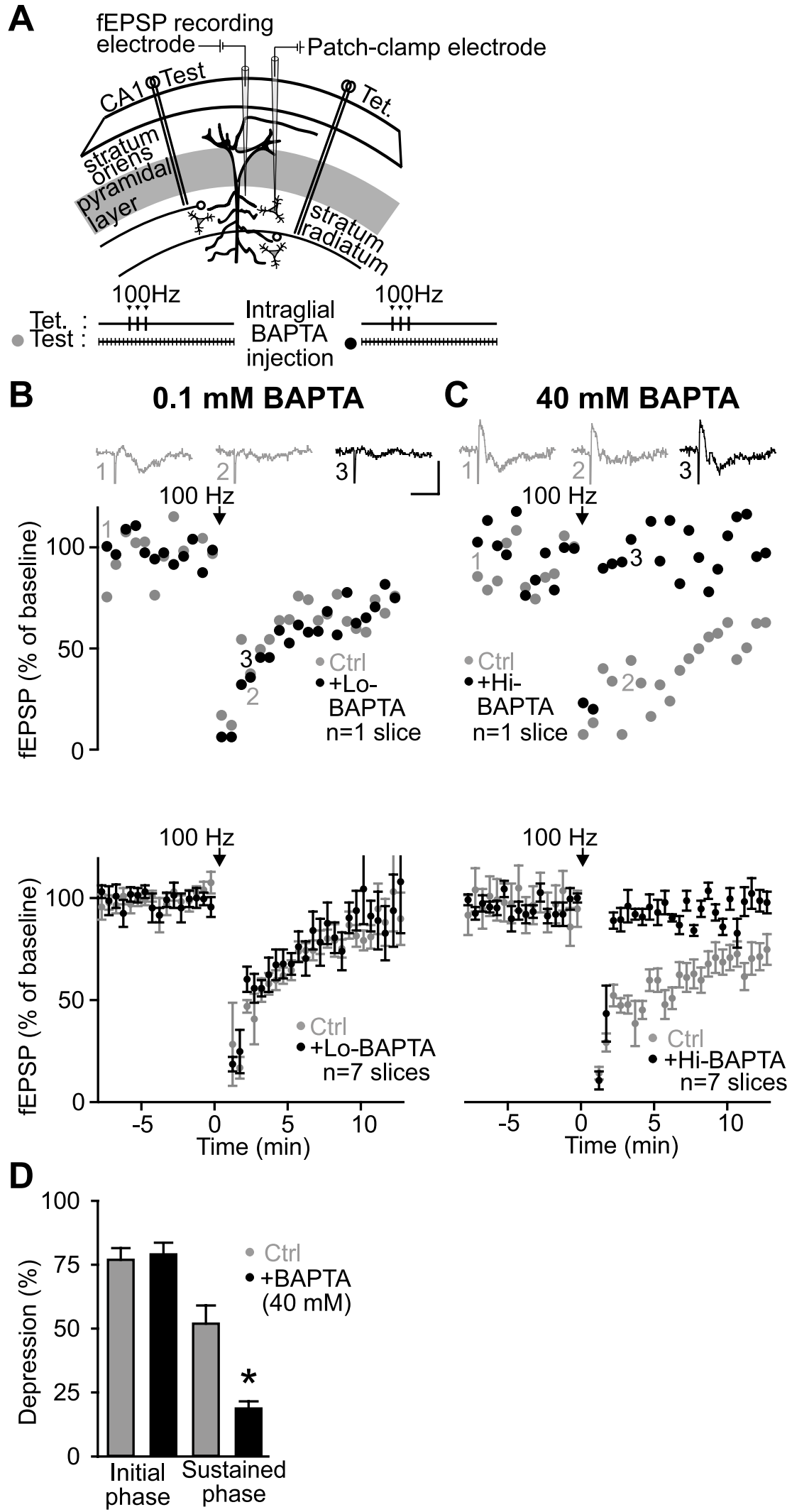

Figure 4. Blockade of heterosynaptic depression by BAPTA dialysis in glial cells. $A$, Schematic representation of area $C A 1$ in a rat hippocampal slice, showing positions of two stimulating electrodes [Test; Tet. (tetanus)], a single fEPSP recording electrode placed in the stratum radiatum, and a single whole-cell patch-clamp electrode recording from a glial cell. The experimental protocol is illustrated at the bottom. $\boldsymbol{B}$, Data from a representative slice (top panel) and for all slices (bottom panel; $n=7$ slices) showing changes in fEPSP amplitude as percentage of baseline before, during, and after tetanic stimulation of an independent pathway (arrow) (3 trains at $100 \mathrm{~Hz}$ for $1 \mathrm{~s} ; 30 \mathrm{~s}$ intervals) in paired control experiments (gray) and after whole-cell dialysis of $0.1 \mathrm{~mm}$ BAPTA in the glial syncytium (black). Dialysis of $0.1 \mathrm{~mm}$ BAPTA in glial cells did not affect tetanization- phase of depression of fEPSPs induced by tetanization (Fig. $1 B$ ), was unchanged (to $11.1 \pm 3.9 \%$ of baseline; Student's paired $t$ test; $p>0.4)$; however, half-maximal recovery from depression occurred significantly faster $(1.0 \pm 6.8 \mathrm{~min}$; Student's paired $t$ test; $p<0.03)$, and the depression of fEPSPs during the sustained phase was prevented. In this phase, the fEPSP amplitude was reduced only to $82.5 \pm 2.8 \%$ of baseline ( $n=7$ slices; Student's paired $t$ test; $p<0.01$ ) (Fig. $4 C, D$ ). These results indicate that prevention of $\mathrm{Ca}^{2+}$ mediated activation of glial cells did not affect the initial NMDA-independent phase of depression induced by tetanization, but it inhibited the sustained NMDA-dependent phase of heterosynaptic depression. Hence, $\mathrm{Ca}^{2+}$-mediated activation of glial cells seems necessary for the complete expression of tetanizationinduced heterosynaptic depression. This effect was not caused by the leakage of BAPTA in extracellular space and buffering $\mathrm{Ca}^{2+}$, thus reducing transmitter release, because the presence of the BAPTAcontaining patch pipette for $30 \mathrm{~min}$ in slices did not affect fEPSP amplitude (data not shown).

Indirect mechanism of glial cell activation during NMDA-induced synaptic depression

We next investigated whether glial cells could be activated directly by NMDA (Schipke et al., 2001) during NMDAinduced synaptic depression. To test this possibility, we applied NMDA in the presence of TTX $(1 \mu \mathrm{M})$ to block action potential propagation and synaptic transmis-

induced heterosynaptic depression (Student's paired $t$ test; $p>0.3$ ). Top panel insets show examples of fEPSPs before (1) and during (2) heterosynaptic depression in control and after dialysis of $0.1 \mathrm{~mm}$ BAPTA (3). Calibration: $1 \mathrm{mV}, 20 \mathrm{~ms}$. C, Data from a single slice (top panel) and for all slices (bottom panel; $n=7$ slices) showing changes in fEPSP amplitude as percentage of baseline before, during, and after tetanic stimulation of an independent pathway (arrow) (3 trains at 100 $\mathrm{Hz}$ for $1 \mathrm{~s} ; 30$ s intervals) in paired control experiments (gray) and after whole-cell dialysis of $40 \mathrm{~mm}$ BAPTA in the glial syncytium (black). Note that heterosynaptic depression was obliterated in the presence of a high concentration of the $\mathrm{Ca}^{2+}$ chelator. Dialysis of $40 \mathrm{~mm}$ BAPTA in glial cells did not affect the initial phase but reduced significantly the sustained phase of the tetanization-induced heterosynaptic depression (Student's paired $t$ test; $p<0.01$ ). Top panel insets show examples of fEPSPs before (1) and during (2) heterosynaptic depression in control, and in the presence of a high concentration of intraglial BAPTA (3). D, Bar graphs showing the amplitude of the initial and the sustained phase of heterosynaptic depression induced by tetanic stimulation in control (gray) and after dialysis of $40 \mathrm{~mm}$ BAPTA (black). Error bars indicate SEM. Ctrl, Control. ${ }^{*} p<0.05$. 
sion. The NMDA-induced rise of $\mathrm{Ca}^{2+}$ in glial cells showed significant rundown with repeated application of NMDA (57.9 \pm $12.3 \%$ of control; Student's $t$ test; $p<0.01$ ) (Figs 3D, 5A). In TTX, the NMDA-induced rise of $\mathrm{Ca}^{2+}$ in glial cells was significantly reduced to $30.6 \pm 13.0 \%$ of control $(n=56$ cells in nine slices; Student's paired $t$ test; $p<0.001$ ) (Fig. $5 B, C$ ). Moreover, the time-to-peak of the $\mathrm{Ca}^{2+}$ rise was $12.4 \pm 0.6 \mathrm{~min}$ in TTX, which was significantly delayed relative to control conditions (9.1 $\pm 0.5 \mathrm{~min}$ in control). Also, in the presence of TTX, the number of responsive glial cells per field of view in a slice was significantly reduced by $69.2 \pm 5.4 \%$ (Student's paired $t$ test; $p<$ 0.001) (Fig. 5C). Our results suggest that $\mathrm{Ca}^{2+}$-mediated glial activation during NMDA-induced depression was indirect and involved neuronal elements.

Additionally, we tested whether coupling of glial cells after NMDA application was also affected by TTX. Dialysis of biocytin in a single glial cell resulted in labeling of a reduced number of cells ( $2.7 \pm 1.2$ cells; $n=3$ slices). After application of NMDA, the number of biocytin-labeled glial cells was $123.3 \pm 53.6$ cells $(n=$ 10 slices) (Fig. $3 A$ ); however, after application of NMDA in the presence of TTX, only $4.3 \pm 1.8$ glial cells $(n=3$ slices $)$ were labeled with biocytin (Student's paired $t$ test; $p<0.05$ ). These results suggest that NMDA-induced coupling of glial cells is also indirect and involves activation of the neuronal network.

We next wondered whether indirect glial activation involved glutamate release from Schaffer collaterals and activation of metabotropic glutamate receptors (mGluRs) (Porter and McCarthy, 1996; Latour et al., 2001). In the presence of E4CPG (400 $\mu \mathrm{M})$, a group I/II mGluR antagonist, neither the NMDA-induced synaptic depression nor the $\mathrm{Ca}^{2+}$ rise in glial cells was affected. NMDA depressed fEPSPs to $11.7 \pm 3.8 \%$ of baseline in control and to $15.4 \pm 3.2 \%$ of baseline in the presence of E4CPG $(n=4$ slices; Student's paired $t$ test; $p>0.4$; data not shown). Also, when glial $\mathrm{Ca}^{2+}$ responses were monitored with fEPSP recordings, NMDA-induced a $\mathrm{Ca}^{2+}$ rise of $51.7 \pm 6.1 \% \Delta F / F$ in glial cells in control conditions and of $51.6 \pm 5.7 \% \Delta F / F$ in the presence of E4CPG ( $n=8$ cells in two slices; Student's paired $t$ test; $p>0.6$; data not shown). Our results indicate that group I/II mGluR activation is not involved in either the NMDA-induced depression of fEPSP or the $\mathrm{Ca}^{2+}$ responses in glial cells.

\section{Role of GABA in heterosynaptic depression and activation of glial cells}

Because hippocampal GABA interneurons express NMDA receptors (Freund and Buzsaki, 1996) and their activation elicits $\mathrm{GABA}_{\mathrm{B}}$-mediated $\mathrm{Ca}^{2+}$ rises in glial cells (Kang et al., 1998), we next tested whether the GABAergic system contributes to heterosynaptic depression. Heterosynaptic depression was measured simultaneously with $\mathrm{Ca}^{2+}$ levels in glial cells in control conditions and in the presence of the $\mathrm{GABA}_{\mathrm{B}}$ antagonist CGP55845. In the presence of CGP55845 (2 $\mu \mathrm{M})$, both the tetanus-induced rise of $\mathrm{Ca}^{2+}$ in glial cells and the heterosynaptic depression of fEPSPs were significantly reduced (Fig. 6A, $B$ ). As shown in Figure $6 A$, in CGP55845 $(2 \mu \mathrm{M})$ fEPSPs were only depressed to $81.3 \pm 4.6 \%$ of baseline, compared with $31.2 \pm$ $5.7 \%$ of baseline in control $(n=3$ slices; Student's paired $t$ test; $p<0.001$ ), whereas the glial $\mathrm{Ca}^{2+}$ response induced by the stimulation was blocked ( $n=15$ cells in three slices; Student's paired $t$ test; $p<0.01$ ) (Fig. 6 B). These findings appear inconsistent with those of Manzoni et al. (1994), who found that the less potent $\mathrm{GABA}_{\mathrm{B}}$ antagonist CGP35348 did not prevent NMDA- and tetanus-induced heterosynaptic depression. This discrepancy may result from the different efficacy of the $\mathrm{GABA}_{\mathrm{B}}$ receptor
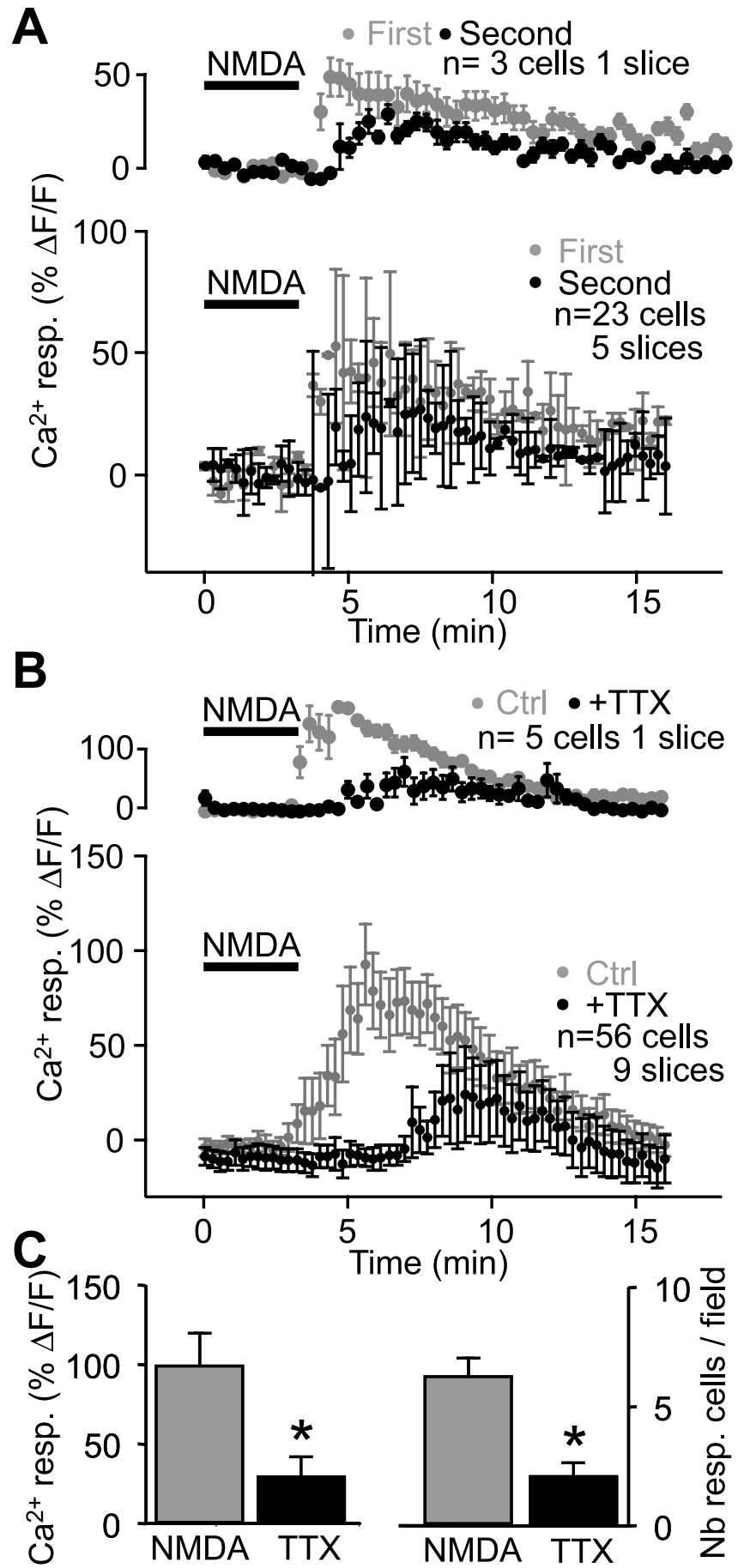

Figure 5. Indirect $\mathrm{Ca}^{2+}$ activation of glial cells during NMDA-induced depression. $\boldsymbol{A}$, Relative increase (mean $\pm S E M$ ) in fluorescence for glial cells in a representative single slice (top panel; $n=3$ cells) and for all slices (bottom panel; $n=23$ cells, 5 slices) before, during, and after two consecutive NMDA bath applications (bar), showing a small rundown in $\mathrm{Ca}^{2+}$ response to the second NMDA application (first, gray; second, black; paired experiments). $\boldsymbol{B}$, Relative increase (mean \pm SEM) in fluorescence for glial cells in a representative slice (top panel; $n=5$ cells) and for all slices (bottom panel; $n=56$ cells, 9 slices) before, during, and after NMDA bath application (bar) in control (gray) and in the presence of TTX ( $1 \mu \mathrm{m}$; black; paired experiments). The rise of $\mathrm{Ca}^{2+}$ in glial cells elicited by NMDA $(25 \mu \mathrm{m})$ was significantly reduced and delayed in the presence of TTX. C, Bar graphs depicting the peak amplitude of glial $\mathrm{Ca}^{2+}$ responses and the number of responsive glial cells induced by NMDA in control (gray) and in TTX (black). Note the significant reduction in the amplitude of the responses and in the percentage of responsive cells (Student's paired $t$ test; ${ }^{*} p<0.001$ ). Error bars indicate SEM. Ctrl., Control; resp., response. 


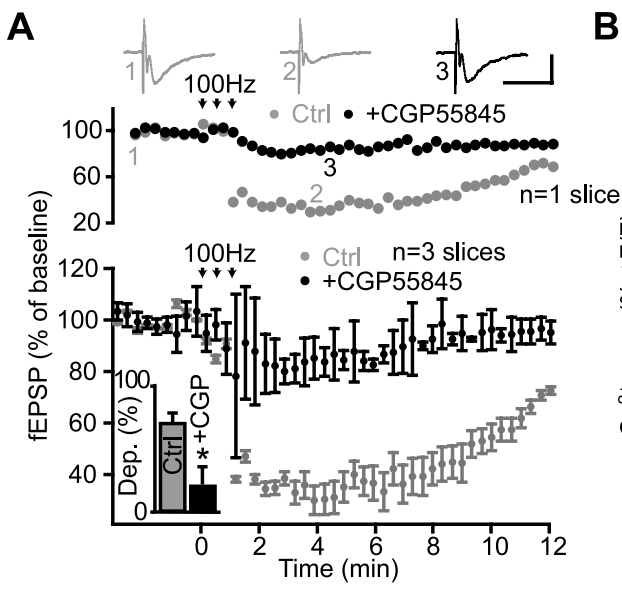

B

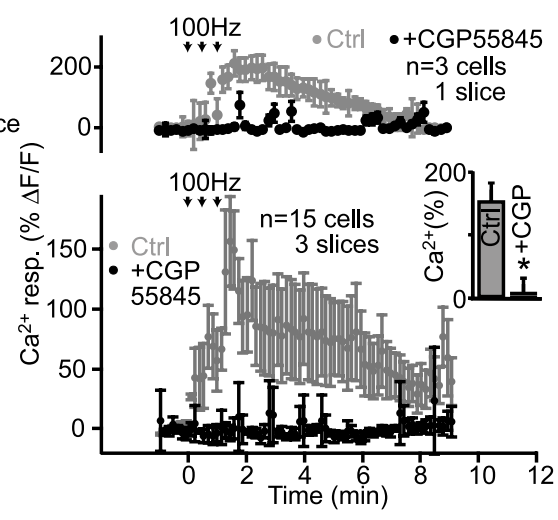

Figure 6. $\mathrm{GABA}_{\mathrm{B}}$ receptor activation is necessary for heterosynaptic depression. $\boldsymbol{A}$, Data from a single slice (top panel) and for all slices (bottom panel; $n=3$ slices) showing changes in fEPSP amplitude as percentage of baseline before, during, and after tetanic stimulation of an independent pathway (arrows) (3 trains at $100 \mathrm{~Hz}$ for $1 \mathrm{~s} ; 30$ s intervals) in paired control experiments (gray) and in the presence of the $\mathrm{GABA}_{\mathrm{B}}$ receptor antagonist CGP55845 (2 $\mu \mathrm{m}$; black). Summary bar graph (inset) shows that heterosynaptic depression was reduced significantly by the $\mathrm{GABA}_{\mathrm{B}}$ receptor antagonist (Student's paired $t$ test; ${ }^{*} p<0.001$ ). Top panel insets show examples of fEPSPs before (1) and during (2) heterosynaptic depression in control and in the presence of CGP55845 (3). Calibration: $1 \mathrm{mV}, 25 \mathrm{~ms}$. B, Relative increase (mean \pm SEM) in fluorescence for glial cells in a single slice (top panel; $n=3$ cells; same slice as in $A$ ) and for all slices (bottom panel; $n=15$ cells, 3 slices) before, during, and after tetanic stimulation in control and in the presence of CGP55845 (2 $\mu \mathrm{m}$; same experiments as in A). Summary bar graph (inset) shows the rise of $\mathrm{Ca}^{2+}$ in glial cells elicited by tetani that was blocked by CGP55845 (Student's paired $t$ test; ${ }^{*} p<0.01$ ). Error bars indicate SEM. Ctrl., Control; resp., response.

antagonists used (Davies et al., 1993). To examine this possibility, we tested the effect on heterosynaptic depression of CGP35348 and another new generation GABA $_{\mathrm{B}}$ antagonist, CGP54626. When tested in the same slices, depression of fEPSPs was not significantly different in control (to $74.2 \pm 0.8 \%$ of baseline) and in the presence of CGP35348 (to $75.5 \pm 2.2 \%$ of baseline; $n=3$ slices; $p>0.05$; ANOVA; Tukey's test) but was significantly reduced in the presence of CGP54626 (to $91.4 \pm 0.7 \%$ of baseline; $p<0.001$; ANOVA; Tukey's test). These data suggest that neuronal and glial $\mathrm{GABA}_{\mathrm{B}}$ receptors may differ in terms of pharmacological profile, but, moreover, clearly indicate that $\mathrm{Ca}^{2+}$. mediated glial activation during heterosynaptic depression requires $G_{A B A}$ receptors. Hence, these data suggest that the inhibition of NMDA-induced glial activation by TTX (Fig. $5 B$ ) is caused by the block of action potential propagation in GABAergic cells and reduction of GABA release. These results further suggest that the indirect $\mathrm{Ca}^{2+}$-mediated activation of glial cells during the NMDA-induced depression involves the GABAergic system.

We next asked whether $\mathrm{GABA}_{\mathrm{B}}$ receptors were involved in NMDA-induced heterosynaptic depression. In control, NMDA depressed fEPSP amplitude to $1.6 \pm 4.2 \%$ of baseline with a peak at $12.9 \pm 2.3 \mathrm{~min}$ after drug onset, whereas fEPSPs were only reduced to $41.1 \pm 9.3 \%$ of baseline at $11.5 \pm 0.8 \mathrm{~min}$ after drug onset in the presence of CGP55845 ( $2 \mu \mathrm{M} ; n=6$ slices; Student's paired $t$ test; $p<0.01$ ) (Fig. 7A). In CGP55845, the glial $\mathrm{Ca}^{2+}$ response induced by NMDA was completely abolished $(n=47$ cells in six slices; Student's paired $t$ test; $p<0.001$ ) (Fig. $7 B$ ). Thus, NMDA-induced depression and heterosynaptic depression share another common step: the activation of $\mathrm{GABA}_{\mathrm{B}}$ receptors.

We next tested whether bypassing local GABA release and directly activating $\mathrm{GABA}_{\mathrm{B}}$ receptors with an agonist would induce fEPSP depression and $\mathrm{Ca}^{2+}$ responses in glial cells. As shown in Figure $7 C$, bath application of the $\mathrm{GABA}_{\mathrm{B}}$ agonist baclofen $(20 \mu \mathrm{M})$ depressed fEPSPs to $5.6 \pm 5.0 \%$ of baseline, with the maximal effect at $10.7 \pm 2.3$ min after onset of drug application $(n=$ 6 slices), which was blocked by CGP55845 $(2 \mu \mathrm{M})$. Moreover, the same bath application of baclofen induced a glial $\mathrm{Ca}^{2+}$ response of $57.0 \pm 19.5 \%$ $\Delta F / F$ that peaked at $8.3 \pm 3.6 \mathrm{~min}$ after the onset of drug application $(n=33$ cells in six slices) (Fig. 7D). The baclofen-induced rise of $\mathrm{Ca}^{2+}$ in glial cells was blocked also by CGP55845 (Student's paired $t$ test; $p<0.01$ ). The glial $\mathrm{Ca}^{2+}$ responses induced by baclofen are unlikely to be indirect, because they were unaffected by TTX (1 $\mu \mathrm{M})(n=12$ cells; Student's paired $t$ test; $p>0.5)$. Thus, the results of these series of experiments indicate that $\mathrm{GABA}_{\mathrm{B}}$ receptor activation is necessary and sufficient for $\mathrm{Ca}^{2+}$-mediated glial activation and fEPSP depression, suggesting a critical interaction between the GABAergic network and glial cells in heterosynaptic depression. Moreover, these data suggest that activation of glial $\mathrm{GABA}_{\mathrm{B}}$ receptors occurs downstream from GABA release in the induction cascade of heterosynaptic depression, because the $\mathrm{GABA}_{\mathrm{B}}$ agonist directly activated glial cells.

\section{Is $\mathrm{Ca}^{2+}$-mediated activation of glial cells necessary for NMDA- or baclofen-induced depression?}

Given the role of $\mathrm{Ca}^{2+}$ activation of glial cells in heterosynaptic depression, we next examined whether glial $\mathrm{Ca}^{2+}$ activation is also necessary for NMDA-induced synaptic depression. Because bath application of NMDA will activate a number of cellular elements, such as inhibitory interneurons, and consequently affect a larger number of glial cells than those dialyzed with BAPTA, one would predict that BAPTA dialysis in glial cells would reduce, but not completely block, the NMDA-induced depression. In control experiments (i.e., $0.1 \mathrm{~mm}$ BAPTA in patch electrode), 25 $\mu \mathrm{M}$ NMDA similarly depressed fEPSP amplitude before (to $5.4 \pm$ $2.7 \%$ of baseline) and after (to $8.7 \pm 4.5 \%$ of baseline) BAPTA dialysis in glial cells ( $n=7$ slices; Student's paired $t$ test; $p>0.3$ ) (Fig. 8A). After dialysis of $40 \mathrm{~mm}$ BAPTA, however, NMDA depressed fEPSPs only to $30.8 \pm 7.6 \%$ of baseline in comparison with $0.1 \pm 8.4 \%$ of baseline in control ( $n=9$ slices; Student's paired $t$ test; $p<0.02$ ) (Fig. $8 B, C$ ). Recovery from depression was also significantly faster (half-maximal recovery, $10.5 \pm 0.8 \mathrm{~min}$ before and $8.0 \pm 1.2 \mathrm{~min}$ after BAPTA dialysis; Student's paired $t$ test; $p<0.03)$. Additionally, none of these changes could be explained by baseline variations in fEPSP because control experiments with vehicle (ACSF) application and whole-cell recording with BAPTA-free patch solution remained stable throughout the entire test period (Fig. $8 \mathrm{~B}$ ). These results indicate that preventing $\mathrm{Ca}^{2+}$ activation in glial cells significantly reduced NMDAinduced synaptic depression.

We tested next whether baclofen-induced depression was reduced by chelating $\mathrm{Ca}^{2+}$ in glial cells. Given the importance of presynaptic $\mathrm{GABA}_{\mathrm{B}}$ inhibition of glutamatergic synapses (Isaacson et al., 1993), one can predict that only a fraction of the baclofen-induced depression should be blocked by BAPTA dial- 
ysis in glial cells. Indeed, after BAPTA (40 $\mathrm{mM}$ ) was dialyzed into glial cells, baclofen depressed fEPSPs only to $30.7 \pm 2.0 \%$ of baseline in comparison with $18.2 \pm 1.5 \%$ of baseline in control ( $n=5$ slices; Student's paired $t$ test; $p<0.001$ ) (Fig. $8 D, E$ ). Note that in these experiments, NMDA application was needed between the preand post-BAPTA baclofen applications to allow BAPTA-biocytin to spread into the syncytium. In control experiments, without BAPTA dialysis in glial cells, repeated applications of baclofen produced similar fEPSP depression (Fig. 8 F). These results indicate that inhibition of $\mathrm{Ca}^{2+}$ activation in glial cells reduced a small but significant portion of baclofen-induced depression.

\section{Adenosine $A_{1}$ receptor involvement in heterosynaptic depression but not in glial cell activation}

To confirm that heterosynaptic depression is caused by adenosine activating $\mathrm{A}_{1}$ receptors at Schaffer collateral synapses (Manzoni et al., 1994), we induced heterosynaptic depression in the presence of CPT, an antagonist of $\mathrm{A}_{1}$ adenosine receptors. Bath perfusion of CPT $(2 \mu \mathrm{M})$ significantly reduced heterosynaptic depression of fEPSP amplitude from $46.1 \pm 3.2 \%$ of baseline in control to only $76.4 \pm 6.3 \%$ of baseline in the presence of CPT ( $n=5$ slices; Student's paired $t$ test; $p<0.05$ ) (Fig. 9A). Thus, consistent with previous reports (Manzoni et al., 1994), heterosynaptic depression depends on adenosine release and activation of $A_{1}$ receptors. Because adenosine elicits $\mathrm{Ca}^{2+}$ elevations in glial cells (Porter and McCarthy, 1995) and glial cells release adenosine and ATP (Cotrina et al., 1998, 2000; Guthrie et al., 1999; Wang et al., 2000; Newman, 2003), we tested the sensitivity of tetanus-induced $\mathrm{Ca}^{2+}$ rises in glial cells to CPT $(2 \mu \mathrm{M})$. As shown in Figure $9 B$, the peak of the tetanus-induced $\mathrm{Ca}^{2+}$ rises in glial cells was not affected significantly by CPT ( $n=$ 16 cells in 3 slices; Student's paired $t$ test; $p>0.3)$. In control, the peak $\mathrm{Ca}^{2+}$ rise was $64.7 \pm 39.1 \% \Delta F / F$, whereas in CPT, the peak $\mathrm{Ca}^{2+}$ response was $80.1 \pm 53.7 \% \Delta F / F$. These results confirm that tetanus-induced glial cell activation is not mediated via $\mathrm{A}_{1}$ receptors and extracellular release of adenosine. Thus, because adenosine is necessary for the induction of heterosynaptic depression and because glial cell activation is not dependent on adenosine release, these results suggest that adenosine release occurs downstream from glial cell activation.

We next tested whether NMDA-induced depression also depends on $\mathrm{A}_{1}$ receptor activation (Manzoni et al., 1994). We measured NMDA-induced depression in control conditions and in the presence of bath-applied CPT in the same slices. In control, NMDA depressed fEPSPs to $12.8 \pm 5.0 \%$ of baseline, but only to $46.1 \pm 10.7 \%$ of baseline in CPT $(n=5$ slices; Student's paired $t$
B

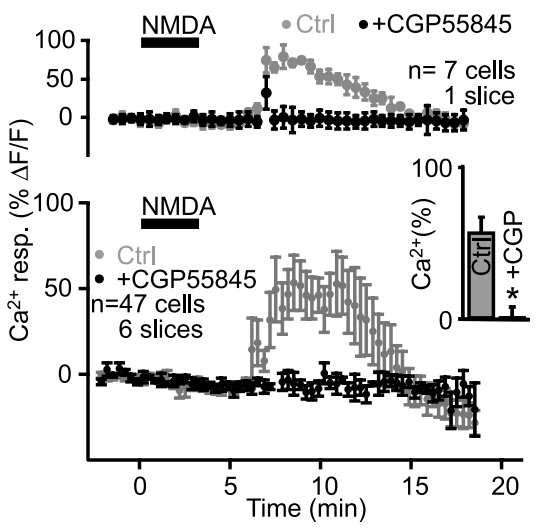

D

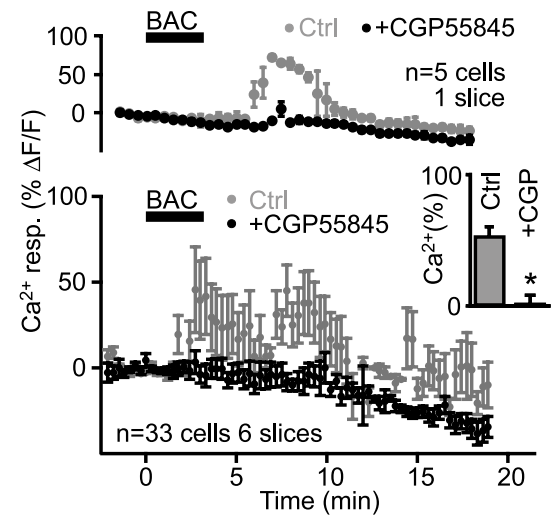

Figure 7. $G_{B B A}$ receptor activation is involved in NMDA- and baclofen-induced depression. $\boldsymbol{A}$, Data from a single slice (top panel) and for all slices (bottom panel; $n=6$ slices) showing changes in fEPSP amplitude as percentage of baseline before, during, and after NMDA bath application ( $25 \mu \mathrm{m} ; 3 \mathrm{~min}$ ) (bar) in paired control experiments (gray) and in the presence of the GABA (inset) shows the significant reduction of NMDA-induced depression by CGP55845 (Student's paired $t$ test; ${ }^{*} p<0.01$ ). Top panel insets show examples of fEPSPs before (1) and during (2) synaptic depression in control, and in the presence of CGP55845 (3). Calibration: $0.5 \mathrm{mV}, 20 \mathrm{~ms}$. B , Relative increase (mean \pm before, during, and after NMDA bath application ( $25 \mu \mathrm{M})$ in control (gray) and in the presence of CGP55845 (2 $\mu \mathrm{m}$; black). Summary bar graph (inset) shows the blockade of NMDA-induced glial Ca ${ }^{2+}$ responses by CGP55845 (Student's paired $t$ test; ${ }^{*} p<0.001$; same experiments as in $A$ ). C, Data from single slice (top panel) and for all slices (bottom panel; $n=6$ slices) showing changes in fEPSP amplitude as percentage of baseline before, during, and after bath application of the $G_{B B A}$ receptor agonist baclofen (20 $\mu \mathrm{m} ; 3 \mathrm{~min}$ ) (bar) in paired control experiments (gray) and in the presence of CGP55845 (2 $\mu \mathrm{m}$; black). Bar graph (inset) depicting the baclofen-induced reduction in fEPSP amplitude (gray) blocked by the GABA ${ }_{B}$ receptor antagonist CGP55845 (black; Student's paired $t$ test; ${ }^{*} p<0.01$ ). Top panel insets show examples offEPSPs before (1) and during (2) synaptic depression glial cells in a single slice (top panel; $n=5$ cells) and for all slices (bottom panel; $n=33$ cells, 6 slices) before, during, and after baclofen bath application (20 $\mu \mathrm{m}$ ) in control (gray) and in the presence of $2 \mu \mathrm{M}$ CGP55845 (black; paired experiments; same CGP55845. Glial $\mathrm{Ca}^{2+}$ responses were prevented by the $\mathrm{GABA}_{\mathrm{B}}$ receptor antagonist (Student's paired $t$ test; $\left.{ }^{*} p<0.01\right)$. Error bars indicate SEM. BAC, Baclofen; Ctrl, control; resp., response.

test; $p<0.05$ ) (Fig. 9C). The remaining depression may be the result of the direct presynaptic $\mathrm{GABA}_{\mathrm{B}}$ inhibition caused by the NMDA activation of interneurons and GABA release. Thus, NMDA-induced depression and heterosynaptic depression share a dependence on adenosine release and $\mathrm{A}_{1}$ receptor activation. We also tested whether adenosine activation of $\mathrm{A}_{1}$ receptors occurs downstream of NMDA-induced $\mathrm{Ca}^{2+}$ responses in glial cells by examining the sensitivity of NMDA-induced $\mathrm{Ca}^{2+}$ rises in glial cells to CPT $(2 \mu \mathrm{M})$. Neither the peak nor the time-to-peak of the NMDA-induced $\mathrm{Ca}^{2+}$ rises in glial cells were affected significantly by CPT ( $n=43$ cells in five slices; Student's paired $t$ test; $p>$ 

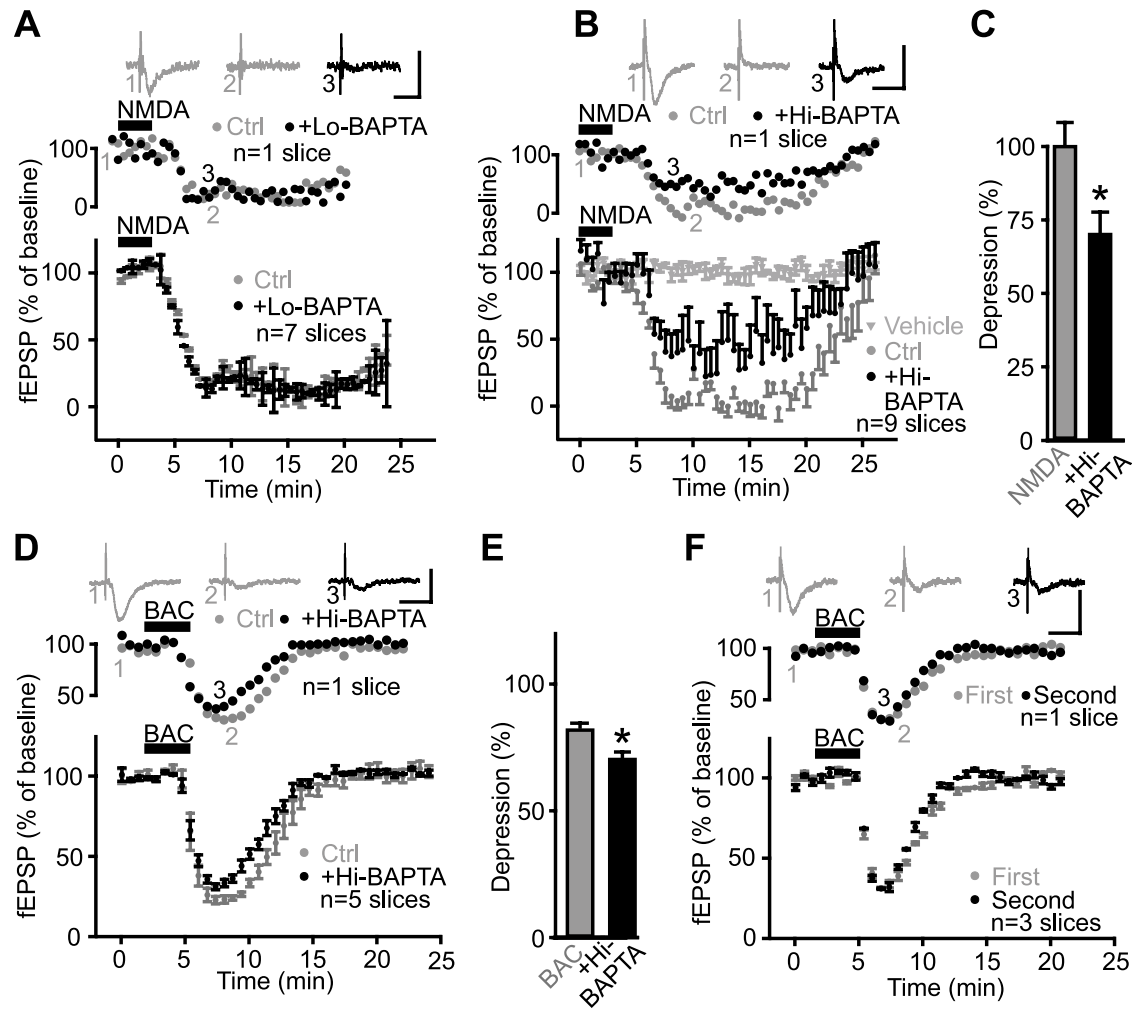

Figure 8. Effects of glial BAPTA dialysis on NMDA- and baclofen-induced depression. $A$, Data from a single slice (top panel) and for all slices (bottom panel; $n=7$ slices) showing changes in fEPSP amplitude as percentage of baseline before, during, and after NMDA bath application (25 $\mu \mathrm{m}$ ) in paired control experiments (gray) and after $0.1 \mathrm{~mm}$ BAPTA dialysis into glial cells (black). Top panel insets show examples of fEPSPs before (1) and during (2) synaptic depression in control, and in the presence $0.1 \mathrm{~mm}$ BAPTA in the glial syncytium (3). Calibration: $0.5 \mathrm{mV}, 20 \mathrm{~ms}$. The presence of $0.1 \mathrm{~mm}$ BAPTA in glial cells did not affect NMDA-induced depression (Student's paired $t$ test; $p>0.3$ ). B, Data from a single slice (top panel) and for all slices (bottom panel; $n=9$ slices) showing changes in fEPSP amplitude as percentage of baseline before, during, and after NMDA bath application ( $25 \mu \mathrm{m}$ ) in paired control experiments (gray) and after $40 \mathrm{~mm}$ BAPTA dialysis into glial cells (black). Insets show examples of fEPSPs before (1) and during (2) synaptic depression in control and in the presence $40 \mathrm{~mm}$ intraglial BAPTA (3). Calibration: $0.5 \mathrm{mV}, 20 \mathrm{~ms}$. Dialysis of 40 mM BAPTA in glial cells reduced the NMDA-induced depression. fEPSP amplitudes expressed as percentage of baseline were unchanged before, during, and after vehicle application and during whole-cell recording from a glial cell with a solution without BAPTA (gray triangles). C, Bar graphs showing percentage of NMDA-induced depression in control (gray) and in the presence of BAPTA $(40 \mathrm{~mm})$ in the glial syncytium (black). Note the significant reduction of the peak of NMDA-induced depression by the glial BAPTA (Student's paired $t$ test; ${ }^{*} p<0.02$ ). D, Data from a single slice (top panel) and for all slices (bottom panel; $n=5$ slices) showing changes in fEPSP amplitude as percentage of baseline before, during, and after baclofen bath application $(20 \mu \mathrm{M})$ in paired control experiments (gray) and after $40 \mathrm{~mm}$ BAPTA dialysis into the glial syncytium (black). Insets show examples of fEPSPs before (1) and during (2) synaptic depression in control, and in the presence $40 \mathrm{~mm}$ intraglial BAPTA (3). Calibration:0.5 mV, $20 \mathrm{~ms}$. $\boldsymbol{E}$, Bar graphs showing percentage of baclofen-induced depression in control (gray) and in the presence of BAPTA ( $40 \mathrm{~mm}$ ) in the glial syncytium (black). Note the reduction in the baclofen-induced depression (Student's paired $t$ test; ${ }^{*} p<0.001$ ). $\boldsymbol{F}$, Data from a single slice (top panel) and for all slices (bottom panel; $n=3$ slices) showing changes in fEPSP amplitude as percentage of baseline before, during, and after two consecutive baclofen bath applications (paired experiments; $20 \mu \mathrm{M}$ ) (bar). Insets show corresponding fEPSPs before (1) and during $(2,3)$ synaptic depression. Calibration: $0.5 \mathrm{mV}, 20 \mathrm{~ms}$. Error bars indicate SEM. BAC, Baclofen; Ctrl., control; resp., response.

0.2) (Fig. 9D). In control, the peak $\mathrm{Ca}^{2+}$ rise was $128.5 \pm 60.2 \%$ $\Delta F / F$ and occurred at $5.8 \pm 3.0 \mathrm{~min}$ after the onset of drug application, whereas in CPT, the peak $\mathrm{Ca}^{2+}$ response was $128.9 \pm 46.5 \%$ $\Delta F / F$ at $5.9 \pm 2.7 \mathrm{~min}$ after drug application. These results confirm that NMDA-induced glial cell activation is not mediated via $\mathrm{A}_{1}$ receptors and extracellular release of adenosine.

If GABA release is involved in glial cell activation and heterosynaptic depression, then the fEPSP depression induced by the $\mathrm{GABA}_{\mathrm{B}}$ agonist baclofen (Fig. $7 C, D$ ) should be indirectly mediated, in part, by adenosine. To test this requirement, we measured baclofen-induced depression in control conditions and in the presence of bath-applied CPT $(2 \mu \mathrm{M})$. In control, baclofen depressed fEPSP amplitude to $32.6 \pm 5.9 \%$ of baseline but only to $57.0 \pm$
C

$11.4 \%$ of baseline in CPT ( $n=5$ slices; Student's paired $t$ test; $p<0.05$ ) (Fig. $9 E$ ). These values concord with the proportion of the baclofen-induced depression blocked by BAPTA (Fig. $8 E$ ) and with the strong inhibition of glutamate release by presynaptic $\mathrm{GABA}_{\mathrm{B}}$ receptors at Schaffer collaterals. Hence, as for heterosynaptic depression and NMDA-induced depression, baclofeninduced depression also depends on $\mathrm{A}_{1}$ receptor activation for its complete induction. These results indicate that heterosynaptic depression and NMDA- and baclofeninduced depression share pathways that similarly converge toward the release of adenosine.

We next examined whether adenosine or its metabolic precursor ATP (Cotrina et al., 1998, 2000; Guthrie et al., 1999; Wang et al., 2000; Newman, 2003) was released from glial cells in heterosynaptic depression with ARL67156 (Gallagher and Salter, 2003), a specific ectonucleotidase inhibitor known to block ATP degradation. If adenosine is produced from ATP degradation, one would expect that heterosynaptic depression should be reduced in the presence of the ectonucleotidase inhibitor. Indeed, bath application of ARL67156 (100 $\mu \mathrm{M})$ significantly reduced heterosynaptic depression. In control, fEPSPs were depressed to $66.7 \pm 10.9 \%$ of baseline but only to $96.3 \pm 1.4 \%$ of baseline in ARL67156 ( $n=3$ slices; Student's paired $t$ test; $p<0.05$ ) (Fig. 9F). Furthermore, similar results were obtained with another ectonucleotidase inhibitor, DPM (Connolly and Duley, 2000; Zhang et al., 2003). Heterosynaptic depression of fEPSP was to $46.1 \pm 3.2 \%$ of baseline in control and only to $76.4 \pm 6.3 \%$ of baseline in DPM $(10 \mu \mathrm{M} ; n=5$ slices; Student's paired $t$ test; $p<0.05)$. Thus, these results suggest that adenosine mediating heterosynaptic depression is a product of ATP degradation.

\section{Discussion}

We established that heterosynaptic depression at hippocampal Schaffer collateral synapses depends on interactions between both neuronal and glial elements. These results indicate that tetanized Schaffer collaterals release glutamate, stimulating the GABAergic network that in turn activates glial cells, which will feed back onto nontetanized Schaffer collateral synapses to induce heterosynaptic depression (supplemental Fig. 1, available at www.jneurosci.org as supplemental material). These findings reveal a novel interactive role between neuronal networks and glial cells in modulating efficacy at central excitatory synapses.

Glial cell activation is necessary for heterosynaptic depression Heterosynaptic depression was proposed to arise from the release of adenosine by interneurons causing depression of transmitter release (Manzoni et al., 1994). Our data confirm an involvement 
of these cellular elements but further demonstrate the requirement for glial cell activation in heterosynaptic depression.

We found that $\mathrm{Ca}^{2+}$ activation of glial cells precedes heterosynaptic depression and that glial activation appears indirectly mediated by GABA. Indeed, not only was glial activation significantly reduced in TTX, but both heterosynaptic depression and glial cell $\mathrm{Ca}^{2+}$ responses were significantly reduced by $\mathrm{GABA}_{\mathrm{B}}$ receptor antagonists. Heterosynaptic depression was reported previously as $\mathrm{GABA}_{\mathrm{B}}$ independent (Manzoni et al., 1994); however, this discrepancy appears to be because of the different antagonists used. The newer generation and more potent $\mathrm{GABA}_{\mathrm{B}}$ antagonists (CGP55845 and CGP54626) prevent heterosynaptic depression, whereas the less potent antagonist, CGP35348, does not.

Furthermore, the $\mathrm{GABA}_{\mathrm{B}}$ agonist baclofen directly activated glial cells and induced depression, in part independent of presynaptic $\mathrm{GABA}_{\mathrm{B}}$ inhibition. Hence, our data suggest that activation of glial cells during heterosynaptic depression and NMDA- and baclofen-induced depression is indirect via local release of GABA. Interestingly, $\mathrm{GABA}_{\mathrm{B}}$ receptors are expressed in glia (Fraser et al., 1994), and interneuron activation produces $\mathrm{GABA}_{\mathrm{B}}$-mediated $\mathrm{Ca}^{2+}$ activation of glial cells (Kang et al., 1998). This is an intriguing observation, because $\mathrm{GABA}_{\mathrm{B}}$ receptors were not known to be positively linked to $\mathrm{Ca}^{2+}$ homeostasis. Finally, we observed that activation of the GABAergic system is essential for both heterosynaptic depression and glial cell activation. Therefore, activation of the GABAergic network by Schaffer collateral stimulation appears not only necessary but also sufficient for heterosynaptic depression and glial cell activation. Direct recording and selective stimulation of GABA interneurons will be necessary to identify which cells are implicated in heterosynaptic depression. Furthermore, one could have expected that not only NMDA but also AMPA-KA receptors may contribute to GABAergic network activation and induction of heterosynaptic depression. The reasons for such different functional importance of NMDA receptors remain to be elucidated.

Glial activation during heterosynaptic depression does not simply occur in parallel during plasticity, because introduction of a calcium chelator in glial cells blocked heterosynaptic depression. Thus, $\mathrm{Ca}^{2+}$. mediated activation of glial cells is necessary for the induction of heterosynaptic depression; however, whether the glial

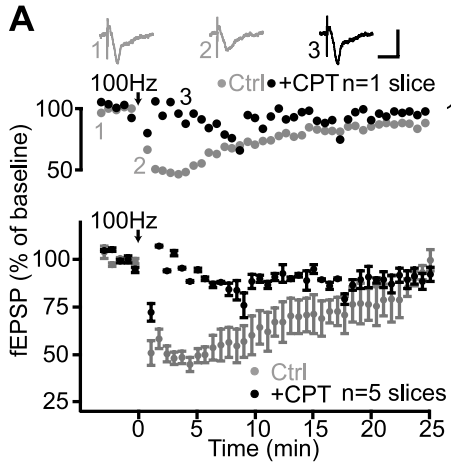

C
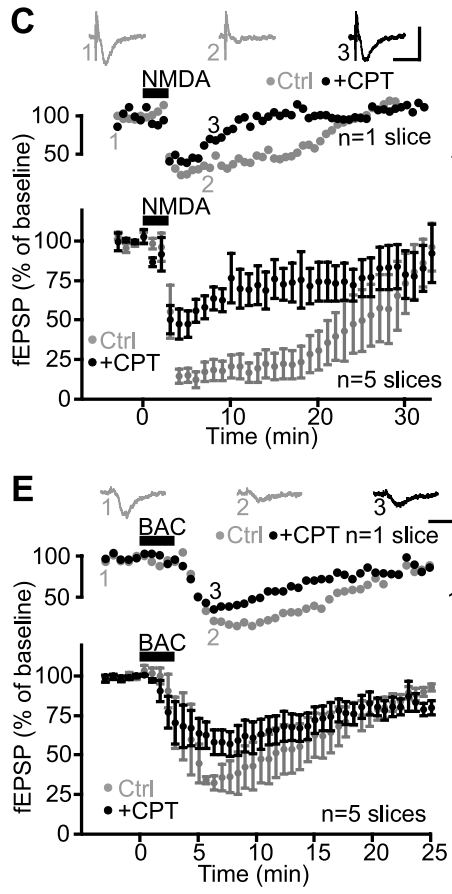

B

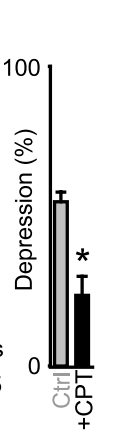

D
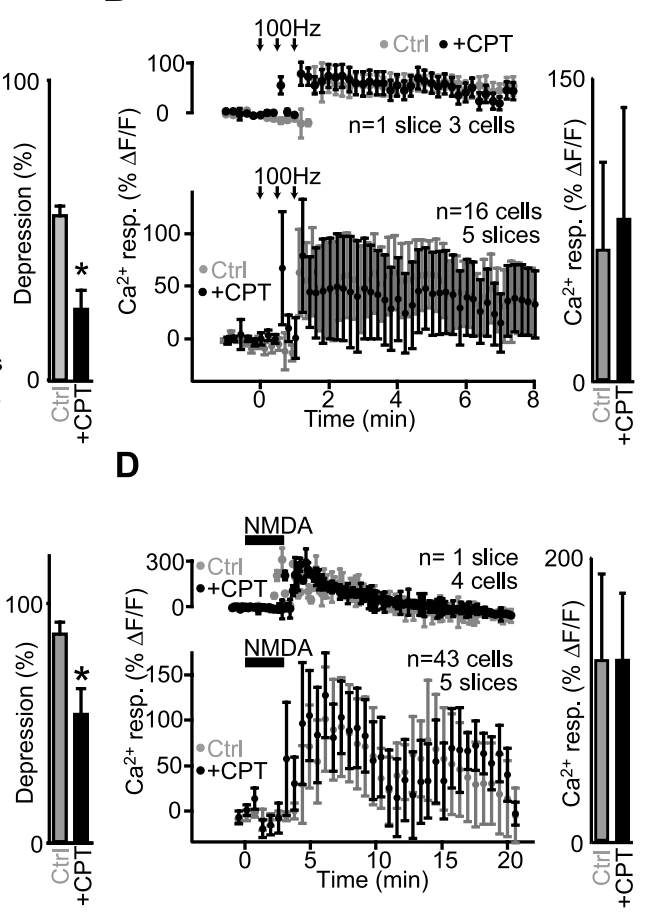

$\mathbf{F}$
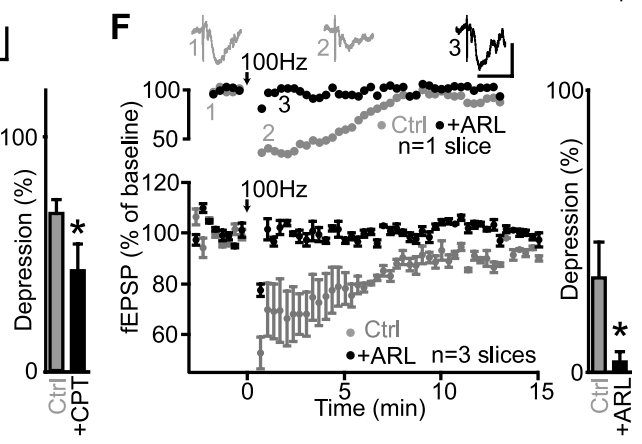

Figure 9. Adenosine $A_{1}$ receptors mediate heterosynaptic depression but are not involved in glial activation. $\boldsymbol{A}$, Data from a single slice (top panel) and for all slices (bottom panel; $n=5$ slices) showing changes in fEPSP amplitude as percentage of baseline before and after tetanic stimulation of an independent pathway (arrows) ( 3 trains at $100 \mathrm{~Hz}$ for $1 \mathrm{~s} ; 30$ s intervals) in paired control experiments (gray) and in the presence of the $A_{1}$ receptor antagonist CPT ( $2 \mu \mathrm{m}$; black). Insets show examples of fEPSPs before (1) and during (2) heterosynaptic depression in control and in the presence of CPT (3). Calibration: $0.5 \mathrm{mV}, 20 \mathrm{~ms}$. Bar graph (right) shows that heterosynaptic depression was significantly reduced by the $A_{1}$ receptor antagonist (Student's paired $t$ test; ${ }^{*} p<0.05$ ). $\boldsymbol{B}$, Relative increase (mean \pm SEM) in fluorescence for glial cells in a single slice (top panel; $n=3$ cells) and for all slices (bottom panel; $n=16$ cells, 5 slices) before, during, and after tetanic stimulation (arrows) ( 3 trains at $100 \mathrm{~Hz}$ for $1 \mathrm{~s} ; 30$ sinterval) showing a calcium rise in control (gray) and in the presence of $2 \mu \mathrm{M}$ (PT (black; paired experiments). Bar graph (right) shows that the $A_{1}$ receptor antagonist had no effect on glial $\mathrm{Ca}^{2+}$ responses evoked by tetanic stimulation (Student's paired $t$ test; $p>0.3$ ). C, Data from a single slice (top panel) and for all slices ( $n=5$ slices) showing changes in fEPSP amplitude as percentage of baseline before, during, and after NMDA bath application ( $25 \mu \mathrm{m})$ in paired control experiments (gray) and in the presence of CPT (2 $\mu \mathrm{M}$; black). Insets show corresponding fEPSPs before (1) and during (2) synaptic depression in control and in the presence of (PT (3). Calibration: $0.5 \mathrm{mV}, 20 \mathrm{~ms}$. Bar graph (right) indicates that NMDA-induced depression was reduced significantly by the $\mathrm{A}_{1}$ receptor antagonist (Student's paired $t$ test; ${ }^{*} p<0.05$ ). D, Relative increase (mean \pm SEM) in fluorescence for glial cells in a single slice (top panel; $n=4$ cells) and for all slices (bottom panel; $n=43$ cells, 5 slices) before, during, and after NMDA bath application ( 25 $\mu \mathrm{M})$ showing a calcium rise in control (gray) and in the presence of $2 \mu \mathrm{M}$ (PT (black; paired experiments). Bar graph (right) shows that the $\mathrm{A}_{1}$ receptor antagonist had no effect on the NMDA-evoked glial $\mathrm{Ca}^{2+}$ responses (Student's paired $t$ test; $\left.p>0.2\right) . E$, Data from a single slice (top panel) and for all slices (bottom panel; $n=5$ slices) showing changes in fEPSP amplitude as percentage of baseline before, during, and after baclofen bath application $(20 \mu \mathrm{M})$ in control (gray) and in the presence of CPT ( $2 \mu \mathrm{M}$; paired experiments). Insets show fEPSPs before (1) and during (2) synaptic depression in control, and in the presence of (PT (3). Calibration: $0.5 \mathrm{mV}, 20 \mathrm{~ms}$. Bar graph (right) shows that baclofen-induced depression was significantly reduced by the $\mathrm{A}_{1}$ receptor antagonist (Student's paired $t$ test; ${ }^{*} p<0.05$ ). $\boldsymbol{F}$, Data from single slice (top panel) and for all slices (bottom panel; $n=3$ slices) displaying changes in fEPSP amplitude as percentage of baseline before, during, and after tetanic stimulation of an independent pathway (arrows) (3 trains at $100 \mathrm{~Hz}$ for $1 \mathrm{~s} ; 30$ s intervals) in control (gray) and in the presence of the ectonucleotidase inhibitor ARL67156 (100 $\mu \mathrm{m}$; black; paired experiments). Insets show fEPSPs before (1) and during (2) heterosynaptic depression in control and in the presence of ARL67156 (3). Calibration: $0.5 \mathrm{mV}, 20 \mathrm{~ms}$. Bar graph (right) shows the significant reduction of heterosynaptic depression by ARL67156 (Student's paired $t$ test; ${ }^{*} p<0.05$ ). Error bars indicate SEM. Ctrl, Control; resp., response. 
$\mathrm{Ca}^{2+}$ rise is sufficient to induce heterosynaptic depression remains to be established. Our data also confirmed an NMDAindependent plasticity, described previously as heterosynaptic suppression (Zhang et al., 2003), that precedes heterosynaptic depression. This early phase of depression was not blocked by D-AP5, CPT, and BAPTA, suggesting that it is distinct from heterosynaptic depression. This early phase may also involve presynaptic $\mathrm{GABA}_{\mathrm{B}}$-mediated depression (Isaacson et al., 1993).

On the basis of our data, a sequence of network interactions underlying heterosynaptic depression can be proposed (supplemental Fig. 1, available at www.jneurosci.org as supplemental material). (1) Glutamate released from tetanized Schaffer collaterals activates GABAergic cells via NMDA receptors; (2) GABA release activates $\mathrm{GABA}_{\mathrm{B}}$ receptors on glial cells, (3) leading to a $\mathrm{Ca}^{2+}$ rise in glial cells, (4) producing ATP release from glial cells, degradation into adenosine, and activation of $A_{1}$ receptors on Schaffer collaterals, and, finally, (5) causing presynaptic inhibition of transmitter release. Hence, our main conclusion is that glial cell activation is necessary for heterosynaptic depression.

It is important to place this model in perspective with other known regulatory mechanisms, such as presynaptic $\mathrm{GABA}_{\mathrm{B}}$ inhibition (supplemental Fig. 1, available at www.jneurosci.org as supplemental material) (Isaacson et al., 1993), to which glial cellmediated heterosynaptic depression will act in complement. Indeed, the lower efficacy of intraglial dialysis of BAPTA on NMDA- and baclofen-induced depression reflects the coexistence of glial-mediated modulation and other neuronal regulatory mechanisms; however, an important functional difference between these regulatory systems is their temporal feature, with presynaptic $\mathrm{GABA}_{\mathrm{B}}$ inhibition occurring in seconds (Isaacson et al., 1993) and heterosynaptic depression occurring in minutes (Manzoni et al., 1994).

\section{Heterosynaptic depression emerges from the cooperation between neuronal and glial networks}

In addition to glial cell activation being necessary for heterosynaptic depression, our data indicate a glial network involvement. Dialysis of a calcium chelator in a single glial cell reduced the responses of numerous glial cells to NMDA, baclofen, or tetanization. Biocytin and Oregon-green BAPTA labeling revealed a network reaching as many as 200 cells over a large area $(\sim 300 \mu \mathrm{m}$ diameter). In contrast, previous studies reported significant dye coupling in hippocampal astrocytes in "unstimulated" slices (D’Ambrosio et al., 1998; Latour et al., 2001; Wallraff et al., 2004). The reasons for these differences in level of dye coupling in basal conditions are unclear, but because synaptic activity was found to regulate glial dye coupling, differences in experimental protocols affecting levels of spontaneous activity may be involved. In any case, reduction of both NMDA- and baclofen-induced depression by calcium buffering in glia suggests a sufficiently extended glial network to modulate synaptic activity over the large area affected by bath-applied agonists. Hence, our data imply that a network of glial cells is involved in heterosynaptic depression and provide the first evidence that interacting neuronal and glial networks are essential in hippocampal heterosynaptic depression.

The involvement of a glial network has several important consequences. First, although single glial cell homosynaptic interactions are sufficient for regulatory feedback (Robitaille, 1998; Auld and Robitaille, 2003a; Zhang et al., 2003), a complex glial network seems necessary for heterosynaptic phenomena. Second, ATP released by glial cells appears pluripotent, mediating $A_{1}$ receptor presynaptic depression and propagation of glial activation (Guthrie et al., 1999; Newman, 2003). Third, a glial network in- volvement implies an extended spatial regulation of synaptic activity in the form of a "center-surround" effect. A center region of tetanized glutamatergic synapses strongly activates pyramidal neurons and the GABAergic network. The latter transfers neuronal information to the glial network, extending beyond the area of activated synapses and depressing surrounding synapses. This center-surround phenomenon increases the contrast between tetanized pyramidal cell synapses and surrounding depressed synapses. Thus, a glial network role is important in spreading neuronal information beyond synapses activated directly by pyramidal cell-GABAergic network interactions. Other previously described glutamatergic neuron-glia interactions (Porter and McCarthy, 1996; Carmignoto et al., 1998; Zhang et al., 2003) likely underlie the small residual $\mathrm{Ca}^{2+}$ elevations in glial cells in the presence of AP5 and may occur in the center region. Obviously, this center-surround phenomenon is lost during agonistinduced depression.

\section{Roles of glial cells in plasticity}

Bidirectional glia-synapse interactions have been described in the CNS (Kang et al., 1998, Araque et al., 1998a, Zhang et al., 2003, Fellin et al., 2004, Pascual et al., 2005) and the PNS (Robitaille, 1998). Interestingly, glial cell vesicular release machinery appears essential for heterosynaptic depression (Pascual et al., 2005). With transgenic mice expressing a dominant-negative soluble $\mathrm{N}$-ethylmaleimide-sensitive factor attachment protein receptor domain in astrocytes to block exocytosis, hippocampal heterosynaptic depression was found to be impaired, suggesting that ATP may be released from astrocytes via vesicular exocytosis during heterosynaptic depression.

Our data represent the first direct evidence that interference with $\mathrm{Ca}^{2+}$ activation of glial cells hampers functional plasticity in neuronal networks. Previous reports of glial cell modulation involved one type of synaptic elements interacting with glial cells (Auld and Robitaille, 2003a), whereas in heterosynaptic depression, three network elements are involved: glutamate synapses activating GABAergic cells; GABA release linking neuronal and glial networks; and glial ATP/adenosine modulating nontetanized synapses.

\section{Perspectives}

Heterosynaptic depression may serve two functions: preventing synaptic saturation by reducing efficacy (Lynch et al., 1977) and increasing contrast between activated and nontetanized synapses (Dunwiddie and Lynch, 1978). It may play a role in hippocampal memory functions because of its relationship with LTP and its effect on synaptic efficacy (Pockett and Lippold, 1986). By showing a glial cell involvement in heterosynaptic depression, we uncovered a novel contribution of glial cells in cognitively relevant synaptic plasticity in the CNS. At present, this role is most relevant to short-term plasticity, and its implication in long-term plasticity remains to be elucidated, although it appears distinct from $\mathrm{A}_{1}$ receptor-independent long-term heterosynaptic depression accompanying LTP (Scanziani et al., 1996).

Our data unveil a novel role of glial cells in a particular form of synaptic plasticity; however, the diversity of glial cell functions, their ability to adapt to synaptic activity (Carmignoto, 2000; Auld and Robitaille, 2003a), and their ubiquitous presence around synaptic elements, are suggestive of glial involvement in other types of plasticity. Thus, we propose that synaptic plasticity is not solely the domain of neurons but also involves glial cells in a complex, "integrated system," with cooperative interactions between neuronal and glial networks. 


\section{References}

Araque A, Parpura V, Sanzgiri RP, Haydon PG (1998a) Glutamatedependent astrocyte modulation of synaptic transmission between cultured hippocampal neurons. Eur J Neurosci 10:2129-2142.

Araque A, Sanzgiri RP, Parpura V, Haydon PG (1998b) Calcium elevation in astrocytes causes an NMDA receptor-dependent increase in the frequency of miniature synaptic currents in cultured hippocampal neurons. J Neurosci 18:6822-6829.

Araque A, Carmignoto G, Haydon PG (2001) Dynamic signaling between astrocytes and neurons. Annu Rev Physiol 63:795-813.

Auld DS, Robitaille R (2003a) Glial cells and neurotransmission: an inclusive view of synaptic function. Neuron 40:389-400.

Auld DS, Robitaille R (2003b) Perisynaptic Schwann cells at the neuromuscular junction: nerve- and activity-dependent contributions to synaptic efficacy, plasticity, and reinnervation. Neuroscientist 9:144-157.

Carmignoto G (2000) Reciprocal communication systems between astrocytes and neurons. Prog Neurobiol 62:561-581.

Carmignoto G, Pasti L, Pozzan T (1998) On the role of voltage-dependent calcium channels in calcium signaling of astrocytes in situ. J Neurosci 18:4637-4645.

Connolly GP, Duley JA (2000) Ecto-nucleotidase of cultured rat superior cervical ganglia: dipyridamole is a novel inhibitor. Eur J Pharmacol 397:271-277.

Cotrina ML, Lin JH, Alves-Rodrigues A, Liu S, Li J, Azmi-Ghadimi H, Kang J, Naus CC, Nedergaard M (1998) Connexins regulate calcium signaling by controlling ATP release. Proc Natl Acad Sci USA 95:15735-15740.

Cotrina ML, Lin JH, Lopez-Garcia JC, Naus CC, Nedergaard M (2000) ATP-mediated glia signaling. J Neurosci 20:2835-2844.

D'Ambrosio R, Wenzel J, Schwartzkroin PA, McKhann II GM, Janigro D (1998) Functional specialization and topographic segregation of hippocampal astrocytes. J Neurosci 18:4425-4438.

Dani JW, Chernjavsky A, Smith SJ (1992) Neuronal activity triggers calcium waves in hippocampal astrocyte networks. Neuron 8:429-440.

Davies CH, Pozza MF, Collingridge GL (1993) CGP 55845A: a potent antagonist of $\mathrm{GABA}_{\mathrm{B}}$ receptors in the $\mathrm{CA} 1$ region of rat hippocampus. Neuropharmacology 32:1071-1073.

Dunwiddie T, Lynch G (1978) Long-term potentiation and depression of synaptic responses in the rat hippocampus: localization and frequency dependency. J Physiol (Lond) 276:353-367.

Fellin T, Pascual O, Gobbo S, Pozzan T, Haydon PG, Carmignoto G (2004) Neuronal synchrony mediated by astrocytic glutamate through activation of extrasynaptic NMDA receptors. Neuron 43:729-743.

Fraser DD, Mudrick-Donnon LA, MacVicar BA (1994) Astrocytic GABA receptors. Glia 11:83-93.

Freund TF, Buzsaki G (1996) Interneurons of the hippocampus. Hippocampus 6:347-470.

Gallagher CJ, Salter MW (2003) Differential properties of astrocyte calcium waves mediated by P2Y1 and P2Y2 receptors. J Neurosci 23:6728-6739.

Guthrie PB, Knappenberger J, Segal M, Bennett MV, Charles AC, Kater SB (1999) ATP released from astrocytes mediates glial calcium waves. J Neurosci 19:520-528.

Haydon PG (2001) GLIA: listening and talking to the synapse. Nat Rev Neurosci 2:185-193.
Isaacson JS, Solis JM, Nicoll RA (1993) Local and diffuse synaptic actions of GABA in the hippocampus. Neuron 10:165-175.

Kang J, Jiang L, Goldman SA, Nedergaard M (1998) Astrocyte-mediated potentiation of inhibitory synaptic transmission. Nat Neurosci 1:683-692.

Koizumi S, Fujishita K, Tsuda M, Shigemoto-Mogami Y, Inoue K (2003) Dynamic inhibition of excitatory synaptic transmission by astrocytederived ATP in hippocampal cultures. Proc Natl Acad Sci USA 100:11023-11028.

Latour I, Gee CE, Robitaille R, Lacaille J-C (2001) Differential mechanisms of $\mathrm{Ca}^{2+}$ responses in glial cells evoked by exogenous and endogenous glutamate in rat hippocampus. Hippocampus 11:132-145.

Lynch GS, Dunwiddie T, Gribkoff V (1977) Heterosynaptic depression: a postsynaptic correlate of long-term potentiation. Nature 266:737-739.

Manzoni OJ, Manabe T, Nicoll RA (1994) Release of adenosine by activation of NMDA receptors in the hippocampus. Science 265:2098-2101.

Newman EA (2003) Glial cell inhibition of neurons by release of ATP. J Neurosci 23:1659-1666.

Pascual O, Casper KB, Kubera C, Zhang J, Revilla-Sanchez R, Sul JY, Takano H, Moss SJ, McCarthy K, Haydon PG (2005) Astrocytic purinergic signaling coordinates synaptic networks. Science 310:113-116.

Pasti L, Volterra A, Pozzan T, Carmignoto G (1997) Intracellular calcium oscillations in astrocytes: a highly plastic, bidirectional form of communication between neurons and astrocytes in situ. J Neurosci 17:7817-7830.

Pasti L, Zonta M, Pozzan T, Vicini S, Carmignoto G (2001) Cytosolic calcium oscillations in astrocytes may regulate exocytotic release of glutamate. J Neurosci 21:477-484.

Pockett S, Lippold OCJ (1986) Long-term potentiation and depression in hippocampal slices. Exp Neurol 91:481-487.

Porter JT, McCarthy KD (1995) Adenosine receptors modulate $\left[\mathrm{Ca}^{2+}\right] \mathrm{i}$ in hippocampal astrocytes in situ. J Neurochem 65:1515-1523.

Porter JT, McCarthy KD (1996) Hippocampal astrocytes in situ respond to glutamate released from synaptic terminals. J Neurosci 16:5073-5081.

Robitaille R (1998) Modulation of synaptic efficacy and synaptic depression by glial cells at the frog neuromuscular junction. Neuron 21:847-855.

Scanziani M, Malenka RC, Nicoll RA (1996) Role of intercellular interactions in heterosynaptic long-term depression. Nature 380:446-450.

Schipke CG, Ohlemeyer C, Matyash M, Nolte C, Kettenmann H, Kirchhoff F (2001) Astrocytes of the mouse neocortex express functional $N$-methylD-aspartate receptors. FASEB J 15:1270-1272.

Serrano A, Haddjeri N, Lacaille JC, Robitaille R (2003) Involvement of glial cells in heterosynaptic depression at hippocampal Schaffer collateralpyramidal cell synapses. Soc Neurosci Abstr 29:378.17.

Wallraff A, Odermatt B, Willecke K, Steinhauser C (2004) Distinct types of astroglial cells in the hippocampus differ in gap junction coupling. Glia 48:36-43.

Wang Z, Haydon PG, Yeung ES (2000) Direct observation of calciumindependent intercellular ATP signaling in astrocytes. Anal Chem 72:2001-2007.

Woodhall G, Gee CE, Robitaille R, Lacaille J-C (1999) Membrane potential and intracellular $\mathrm{Ca}^{2+}$ oscillations activated by mGluRs in hippocampal stratum oriens/alveus interneurons. J Neurophysiol 81:371-382.

Zhang J-M, Wang H-K, Ye C-Q, Ge W, Chen Y, Jiang Z-L, Wu C-P, Poo M-M, Duan S (2003) ATP released by astrocytes mediates glutamatergic activity-dependent heterosynaptic suppression. Neuron 40:971-982. 